Praca poglądowa/Review

Zalecenia ekspertów/Experts' guidelines

\title{
Rekomendacje PALG dotyczące diagnostyki i leczenia przewlekłej białaczki szpikowej w 2013 r.
}

\section{Polish Adult Leukemia Group Recommendations for Diagnosis and Treatment of Chronic Myeloid Leukemia in 2013}

\author{
Tomasz Sacha ${ }^{1, *}$, Krzysztof Lewandowski ${ }^{2}$, Andrzej Hellmann ${ }^{3}$, \\ Joanna Góra-Tybor ${ }^{4}$, Dariusz Woszczyk ${ }^{5}$, Witold Prejzner ${ }^{3}$, \\ Mieczysław Komarnicki ${ }^{2}$, Aleksander B. Skotnicki ${ }^{1}$ \\ ${ }^{1}$ Katedra i Klinika Hematologii Uniwersytetu Jagiellońskiego, Kierownik: prof. zw. dr hab. $n$.med. Aleksander \\ Skotnicki, Kraków, Polska \\ ${ }^{2}$ Katedra i Klinika Hematologii i Chorób Rozrostowych Układu Krwiotwórczego Uniwersytetu Medycznego, Kierownik: \\ prof. dr hab. n. med. Mieczysław Komarnicki, Poznań, Polska \\ ${ }^{3}$ Klinika Hematologii i Transplantologii Gdańskiego Uniwersytetu Medycznego, Kierownik: prof. dr hab. med. Andrzej \\ Hellmann, Gdańsk, Polska \\ ${ }^{4}$ Klinika Hematologii Uniwersytetu Medycznego, Kierownik: prof. dr hab. n. med. Tadeusz Robak, Łódź, Polska \\ ${ }^{5}$ Oddział Hematologii i Onkologii Hematologicznej Szpitala Wojewódzkiego, Ordynator: dr Dariusz Woszczyk, Opole, \\ Polska
}

I N F O R M A C JE O A R T Y K U LE

Historia artykułu:

Otrzymano: 13.06.2013

Zaakceptowano: 05.07.2013

Dostępne online: 17.07 .2013

Słowa kluczowe:

- przewlekła białaczka szpikowa

- aktualne wyniki badań

- rekomendacje diagnozowania, monitorowania i leczenia

Keywords:

- Chronic myeloid leukemia

- Updated clinical results

- Diagnostic, monitoring and

treatment recommendations

\section{A B S T R A C T}

Tyrosine kinase inhibitors (TKIs) have dramatically improved the results of therapy of chronic myeloid leukemia. However the management with more potent second generation TKIs (2GTKIs) is required for imatinib-intolerant and imatinib-resistant patients. The frontline use of 2GTKIs results in higher rates of deeper and faster responses than with imatinib, it can enable many patients to qualify for participation in studies of treatmentfree remission. The BCR/ABL transcript level at 3 months of TKI treatment has become a new prognostic factor. In this paper the recent clinical results of chronic myeloid leukemia therapy with imatinib in first line and with 2GTKIs in first and second line settings are reviewed, and updated PALG recommendations regarding the diagnosis, standard monitoring procedures, definitions of responses and treatment are presented.

(c) 2013 Polskie Towarzystwo Hematologów i Transfuzjologów, Instytut Hematologii i Transfuzjologii. Published by Elsevier Urban \& Partner Sp. z o.o. All rights reserved.

* Adres do korespondencji: Katedra i Klinika Hematologii, Uniwersytetu Jagiellońskiego, ul Kopernika 17, 31-501 Kraków, Polska. Tel.: +48 (12) 4247600.

Adres email: sachatom@gmail.com (T. Sacha).

0001-5814/\$ - see front matter ๑ 2013 Polskie Towarzystwo Hematologów i Transfuzjologów, Instytut Hematologii i Transfuzjologii. Published by Elsevier Urban \& Partner Sp. z o.o. All rights reserved. http://dx.doi.org/10.1016/j.achaem.2013.07.008 


\section{Wstęp}

Przewlekła białaczka szpikowa (PBSz) jest nowotworem mieloproliferacyjnym, o częstości zachorowań 1-2:100 000 osób ogólnej populacji na rok, stanowiącym około 15\% nowo rozpoznanych białaczek u ludzi dorosłych [1]. U większości pacjentów leczenie imatynibem (IM - Glivec, Novartis) [2] pozwala na uzyskanie odpowiedzi cytogenetycznej i molekularnej, a także wydłużenie przeżycia wolnego od zdarzeń (EFS; event-free survival), przeżycia wolnego od progresji (PFS; progression-free survival) i przeżycia całkowitego (OS; overall survival) [3-5]. Około 30\% pacjentów leczonych IM wymaga jednak zmiany terapii ze względu na nietolerancję leku lub oporność [3]. W tej grupie chorych w leczeniu wykorzystuje się m.in. silniej działające inhibitory kinaz tyrozynowych (TKI) II generacji - dazatynib (Sprycel, Bristol-Myers Squibb) i nilotynib (Tasigna, Novartis) [6, 7], jak również zarejestrowany we wrześniu 2012 r. przez FDA, a w styczniu 2013 r. przez EMA, bozutynib (Bosulif, Pfizer) [8]. U chorych z mutacją T315I terapia powyższymi lekami jest nieskuteczna. Dla tych pacjentów lekiem z wyboru będzie najprawdopodobniej TKI III generacji - ponatynib (Iclusig, Ariad Pharmaceuticals), zarejestrowany 14.12.2012 r. przez FDA, który dzięki zdolności wiązania się z izoleucyną w pozycji 315 poprzez tworzenie wiązań van der Waalsa okazał się skuteczny w terapii pacjentów z mutacją T315I, ale także $\mathrm{u}$ chorych bez tej mutacji uprzednio nieskutecznie leczonych pozostałymi TKI $[9,10]$. Bardzo ważnym celem terapeutycznym jest jak najszybsze osiągnięcie całkowitej odpowiedzi cytogenetycznej (CCyR; complete cytogenetic response) i co najmniej większej odpowiedzi molekularnej (MMR; major molecular response). Badania II fazy nad stosowaniem TKI II generacji jako leków pierwszej linii u chorych $\mathrm{z}$ nowo rozpoznaną PBSz wykazały większą ich skuteczność pod względem odsetka i szybkości uzyskiwanych odpowiedzi cytogenetycznych oraz molekularnych i stały się podstawą zarejestrowania przez FDA i EMA dazatynibu i nilotynibu jako leków pierwszej linii. Zarówno amerykańskie (NCCN) jak i europejskie (ESMO) zalecenia rekomendują w pierwszej linii leczenia fazy przewlekłej PBSz wszystkie trzy inhibitory - imatynib, dazatynib lub nilotynib [11, 12]. Od kilku lat bardzo duże zainteresowanie wzbudza możliwość odstawienia TKI u pacjentów, którzy osiągnęli głęboką odpowiedź molekularną [13]. Można przypuszczać, że wprowadzenie do terapii pierwszej linii silniej działających TKI II generacji pozwoli podjąć próbę odstawienia leku u większego odsetka pacjentów. Należy podkreślić, że w chwili obecnej zaprzestanie terapii za pomocą TKI jest możliwe wyłącznie w ramach prób klinicznych [13]. Wprowadzenie TKI II generacji do leczenia pierwszej linii PBSz, informacje dotyczące znaczenia prognostycznego odpowiedzi molekularnej po 3 miesiącach terapii TKI, rejestracja nowych leków (bozutynib, ponatynib, omacetaksyna) i możliwość uzyskania przeżycia wolnego od leczenia (TFS; treatment free survival) spowodowały konieczność sformułowania nowych propozycji postępowania u chorych na PBSz. W artykule przedstawiono aktualne rekomendacje PALG dotyczące diagnostyki i terapii PBSz w świetle nowych danych.

\section{Skale prognostyczne PBSz}

Dotychczas obowiązujące w PBSz skale prognostyczne powstały na podstawie danych uzyskanych od chorych leczonych konwencjonalną chemioterapią [14] lub interferonem $\alpha$ (EURO) [15]. W 2011 r. Hasford i wsp. przedstawili skalę prognostyczną EUTOS opracowaną na podstawie danych pochodzących z rejestru ELN/EUTOS [16] (Tab. I). Nowa skala opiera się na parametrach zwykle ocenianych w chwili ustalania rozpoznania jeszcze przed wdrożeniem jakiegokolwiek leczenia (wielkość śledziony określona palpacyjnie i odsetek bazofili w mikroskopowo ocenianym rozmazie krwi obwodowej) i nie uwzględnia wieku pacjenta. Nie bez znaczenia jest także fakt, że została ona opracowana w oparciu o ocenę pacjentów leczonych TKI. Należy podkreślić, że niezależnie od oceny rokowania za pomocą wyżej wymienionych systemów prognostycznych najważniejszym czynnikiem rokowniczym w chwili rozpoznania PBSz jest faza choroby, a po rozpoczęciu terapii odpowiedź na zastosowane leczenie TKI oceniana w kolejnych badaniach kontrolnych.

\section{Wyniki badań oceniających skuteczność TKI w terapii pierwszej i drugiej linii PBSz}

Wysoką skuteczność IM w leczeniu PBSz potwierdziło randomizowane, dwuramienne badanie kliniczne IRIS (International Randomized Study of Interferon us STI571) [17]. Odnotowano nie tylko znacząco większe odsetki całkowitej odpowiedzi hematologicznej (CHR; complete hematologic response), większych odpowiedzi cytogenetycznych (MCyR; major cytogenetic response) oraz CCyR, ale także dłuższe OS w grupie leczonej IM [17]. Po 8 latach okazało się, że odpowiedzi na IM utrzymują się długotrwale, a ocenione po tym okresie OS i EFS wynosi odpowiednio 85\% i 81\% [18]. Analiza powyższej grupy pacjentów zgodnie z regułą wyjściowej intencji leczniczej (ITT; intent-to-treat analysis) wykazała jednak mniejszy odsetek EFS (63\%) [19, 20]. Mniejszą niż w badaniu IRIS skuteczność IM (CCyR uzyskano u 41\%, 49\% i 51\% odpowiednio po 12, 18 i 24 miesiącach terapii) odnotowano $\mathrm{w}$ badaniu populacyjnym u chorych ze świeżo rozpoznaną PBSz [21]. U 49\% chorych w oparciu o kryteria European LeukemiaNet (ELN) należałoby rozpoznać niepowodzenie terapii z powodu progresji do fazy blastycznej, niemożności uzyskania/utrzymania CCyR lub nietolerancję IM [21]. Uważa się, że chociaż IM jest skuteczny u większości pacjentów, około $30 \%$ nowo zdiagnozowanych chorych na PBSz wymaga bardziej skutecznych form terapii [20], w tym zastosowania TKI II generacji silniej hamujących aktywność kinazy tyrozynowej BCR/ABL.

\section{Wyniki badań oceniających skuteczność TKI II generacji w pierwszej linii terapii PBSz}

Zarówno nilotynib [22], jak i dazatynib [23] zostały w 2010 roku zaaprobowane do leczenia pierwszej linii chorych ze świeżo zdiagnozowaną PBSz w oparciu o wyniki badań 3 fazy (ENESTnd, DASISION), które wykazały, że u pacjentów 
Tabela I - Skale prognostyczne stosowane w PBSz

Table I - Prognostic scores in CML

\begin{tabular}{|c|c|c|c|}
\hline & Sokal et al. [14] & EURO [15] & EUTOS [16] \\
\hline wiek (lata) & 0,116 (wiek - 43,4) & 0,666 dla wieku $>50$ & - \\
\hline śledziona $(\mathrm{cm})^{*}$ & $0,345 \times($ śledziona $-7,51)$ & $0,042 \times$ śledziona & $4 \times$ śledziona \\
\hline płytki $\left(10^{9} / \mathrm{L}\right)$ & $0,188 \times($ płytki/700) $2-0,563$ & 1,0956 dla płytek $\geq 1500$ & - \\
\hline blasty (\%) & $0,887 \times($ blasty $-2,10)$ & $0,0584 \times$ blasty & - \\
\hline eozynofile (\%) & - & $0,0413 \times$ eozynofile & - \\
\hline $\begin{array}{l}\text { bazofile (\%) } \\
\text { ryzyko }\end{array}$ & - & 0,20399 dla bazofili $>3 \%$ & $7 \times$ bazofile \\
\hline - niskie & $<0,8$ & $\leq 780$ & $\leq 87$ \\
\hline - pośrednie & $0,8-1,2$ & $781-1480$ & - \\
\hline - wysokie & $>1,2$ & $>1480$ & $>87$ \\
\hline
\end{tabular}

otrzymujących TKI II generacji osiągana jest głębsza odpowiedź na leczenie, dochodzi do niej szybciej i u większego odsetka chorych niż w grupie leczonej IM. Wysoką skuteczność nilotynibu w terapii pierwszej linii (duży odsetek i szybkość uzyskiwanych CCyR i MMR) wykazały także dwa niezależne badania jednoramienne 2. fazy przeprowadzone przez GIMEMA CML Working Party oraz przez MD Anderson Cancer Center (MDACC) $[24,25]$. Po 3 latach trwania badania grupy GIMEMA okazało się, że profil bezpieczeństwa nilotynibu jest dobry, nie zmienia się w czasie długoterminowego podawania, a uzyskiwane odpowiedzi są trwałe [25]. Badanie ENESTnd wykazało, że nilotinib w dawce $300 \mathrm{mg} 2 \times$ dziennie oraz $400 \mathrm{mg} 2 \times$ dziennie jest bardziej skuteczny niż IM stosowany w dawce $400 \mathrm{mg} / \mathrm{d}$. Odsetek uzyskiwanych MMR po 12 miesiącach leczenia (pierwszorzędowy punkt końcowy badania) wyniósł w badanych grupach odpowiednio 44\%, $43 \%$ oraz $22 \%$. Także odsetek uzyskanych CCyR był znacząco większy w grupach leczonych nilotynibem i wyniósł odpowiednio $80 \%$ i $78 \%$ (IM 65\%) [26]. Podobne tendencje zauważono także po 18, 24, 36 i 48 miesiącach obserwacji [27-31]. Po 48 miesiącach obserwacji odsetek chorych $\mathrm{z}$ poziomem transkryptu $B C R / A B L \leq 0,0032 \%$ IS (redukcja 4.5log, $\mathrm{MR}^{4.5}$ ), co odpowiada według dawnej nomenklatury całkowitej odpowiedzi molekularnej (CMR), w każdym punkcie oceny był istotnie wyższy w obu grupach otrzymujących nilotynib niż $\mathrm{u}$ chorych leczonych IM (odpowiednio 40\%, 37\% i 23\%), ponadto znacznie niższy w tych grupach był odsetek chorych z transformacją do fazy akceleracji lub kryzy blastycznej (odpowiednio 0,7\%, 1,8\% i 6,0\%) [28] (spośród TKI II generacji jedynie dla nilotynibu różnice są istotne statystycznie) (Tab. II), co świadczy o wyższej jakości odpowiedzi uzyskiwanych u chorych leczonych nilotynibem. Doniesienia dotyczące stosowania dazatynibu $w$ pierwszej linii leczenia chorych z PBSz są także bardzo zachęcające. W badaniu 2 fazy przeprowadzonym przez MDACC wykazano, że stosowanie dazatynibu jest powiązane z wczesnym uzyskaniem CCyR oraz MMR u większej liczby chorych niż w grupie leczonej IM [32]. W badaniu 2 fazy przeprowadzonym przez S0325 Intergroup skupiającym północnoamerykańskie grupy badawcze (SWOG, ECOG, CALGB, NCIC-CTG) pierwszorzędowym punktem końcowym był odsetek odpowiedzi molekularnych z redukcją poziomu transkryptu BCR/ $A B L>4 \log$ po 12 miesiącach leczenia dazatynibem lub IM [33]. Odsetek MMR po 10 miesiącach terapii dazatynibem był większy niż w przypadku IM, nie przełożyło się to jednak na wyższy odsetek uzyskiwanych odpowiedzi z redukcją poziomu transkryptu $B C R / A B L>4 \log$ [33]. Oba leki w podobny sposób zapobiegały progresji choroby do AP lub BC i wydłużały przeżycie całkowite. W badaniu DASISION po 12 miesiącach podawania dazatynibu CCyR oraz MMR uzyskano u znacznie większego odsetka chorych niż w przypadku IM (odpowiednio $77 \%$ us $66 \%, p=0,007$ oraz $46 \%$ vs $28 \%$, $p<0,0001)$. Po 24 miesiącach leczenia w każdym punkcie oceny odsetek uzyskiwanych potwierdzonych CCyR oraz MMR był wyższy w grupie osób leczonych dazatynibem, podobnie jak odsetek odpowiedzi > 4log (transkrypt BCR/ABL $\leq 0,01 \%$ ) (odpowiednio $17 \%$ i $8 \%$ ). Ponadto wśród chorych leczonych dazatynibem odnotowano mniej progresji do fazy akceleracji lub kryzy blastycznej (odpowiednio 2,3\% i 5,0\%) [34] (różnice nieistotne statystycznie) (Tab. III).

\section{Wyniki badań oceniających skuteczność leczenia TKI pacjentów z opornością/nietolerancją 1. linii leczenia imatynibem $w$ dawce $400 \mathrm{mg} / \mathrm{d}$}

W randomizowanym badaniu 3. fazy TOPS (tyrosine kinase inhibitor optimization and selectivity) $u$ pacjentów w fazie przewlekłej z niezadowalającą odpowiedzią na IM w dawce $400 \mathrm{mg} / \mathrm{d}$ porównano skuteczność kontynuacji leczenia tą dawką z dawką IM 800 mg/d. Wykazano, że jedynie w 3. i 6 . miesiącu leczenia odsetek chorych uzyskujących MMR wśród osób otrzymujących $800 \mathrm{mg} / \mathrm{d}$ jest wyższy niż w grupie osób leczonych $400 \mathrm{mg} / \mathrm{d}$ leku. Podobna ocena po 12 miesiącach terapii nie wykazała różnic w tym zakresie [35-37]. Innym ocenianym sposobem postępowania u chorych wykazujących nietolerancję lub oporność na IM jest stosowanie TKI II generacji. W badaniu 2. fazy START-C (START; SRC/ABL Tyrosine Kinase Inhibition Activity Research Trials) przeprowadzonym u chorych na PBSz w fazie przewlekłej z opornością lub nietolerancją IM wykazano, że u 90\% pacjentów możliwe jest uzyskanie całkowitej odpowiedzi hematologicznej, a u 52\% chorych częściowej odpowiedzi cytogenetycznej PCyR (PCyR; partial cytogenetic response). U zdecydowanej większości pacjentów odpowiedzi te były trwałe. Przewidywane PFS i OS $\mathrm{u}$ chorych otrzymujących dazatynib wynosiło odpowiednio $96 \%$ i $94 \%$ po 24 miesiącach badania [38, 39]. W badaniu 2. fazy START-R przeprowadzonym $\mathrm{w}$ analogicznej grupie chorych porównano skuteczność dazatynibu w dawce $140 \mathrm{mg} / \mathrm{d} \quad(2 \times 70 \mathrm{mg} / \mathrm{d})$ oraz IM w dawce $800 \mathrm{mg} / \mathrm{d}$ 
Tabela II - Badania kliniczne oceniające skuteczność terapii pierwszego wyboru za pomocą nilotynibu u chorych w fazie przewleklej przewleklej bialaczki szpikowej

Table II - Clinical trials evaluating the efficacy of nilotinib as a first line therapy for chronic myeloid leukemia in chronic phase

\begin{tabular}{|c|c|c|c|c|c|}
\hline Badanie/rodzaj & Populacja & Dawka leku & $\begin{array}{c}\text { Całkowite } \\
\text { odpowiedzi } \\
\text { cytogenetyczne } \\
\text { (CCyR) }\end{array}$ & $\begin{array}{c}\text { Odsetek większych } \\
\text { odpowiedzi } \\
\text { molekularnych } \\
\text { (MMR) }\end{array}$ & $\begin{array}{c}\text { Szacowane } \\
\text { EFS, PFS, FFS, TFS i OS }\end{array}$ \\
\hline $\begin{array}{l}\text { GIMEMA study [25] } \\
\text { jednoramienne, } \\
\text { fazy } 2 \text {. }\end{array}$ & $\begin{array}{l}73 \text { dotychczas } \\
\text { nieleczonych } \\
\text { chorych } \\
\text { w fazie przewlekłej }\end{array}$ & $\begin{array}{l}\text { Nilotynib } \\
400 \text { mg } 2 \times \text { dziennie }\end{array}$ & $\begin{array}{l}\text { 3. miesiąc: } 78 \% \\
\text { 6. miesiąc: } 96 \% \\
\text { 12. miesiąc: } 96 \% \\
\text { 18. miesiąc: } 96 \% \\
\text { 24. miesiąc: } 92 \%\end{array}$ & $\begin{array}{l}\text { 3. miesiąc: } 52 \% \\
\text { 6. miesiąc: } 66 \% \\
\text { 12. miesiąc: } 85 \% \\
\text { 18. miesiąc: } 81 \% \\
\text { 24. miesiąc: } 82 \%\end{array}$ & $\begin{array}{l}\text { 30-miesięczne EFS: 92\% } \\
\text { 30-miesięczne PFS: 99\% } \\
\text { 30-miesięczne FFS: 99\% } \\
\text { 30-miesięczne OS: 99\% }\end{array}$ \\
\hline $\begin{array}{l}\text { MDACC study [26] } \\
\text { jednoramienne, } \\
\text { fazy } 2 \text {. }\end{array}$ & $\begin{array}{l}61 \text { dotychczas } \\
\text { nieleczonych } \\
\text { chorych } \\
\text { w fazie przewlekłej }\end{array}$ & $\begin{array}{l}\text { Nilotynib } \\
400 \text { mg } 2 \times \text { dziennie }\end{array}$ & $\begin{array}{l}\text { 3. miesiąc: } 90 \% \\
\text { 6. miesiąc: } 96 \% \\
\text { 12. miesiąc: } 97 \% \\
\text { 18. miesiąc: } 93 \% \\
\text { 24. miesiąc: } 93 \% \\
\text { 30. miesiąc: } 92 \%\end{array}$ & $\begin{array}{l}\text { 3. miesiąc: } 40 \% \\
\text { 6. miesiąc: } 71 \% \\
\text { 12. miesiąc: } 81 \% \\
\text { 18. miesiąc: } 79 \% \\
\text { 24. miesiąc: } 79 \% \\
\text { 30. miesiąc: } 75 \%\end{array}$ & $\begin{array}{l}\text { 24-miesięczne EFS: 90\% } \\
\text { 24-miesięczne TFS: 98\% }\end{array}$ \\
\hline ENESTnd [27-31] & $\begin{array}{l}846 \text { świeżo } \\
\text { zdiagnozowanych } \\
\text { chorych } \\
\text { w fazie przewlekłej }\end{array}$ & $\begin{array}{l}\text { Nilotynib } \\
300 \text { mg } 2 \times \text { dziennie }^{a} \\
(\mathrm{n}=282)\end{array}$ & $\begin{array}{l}\text { 12. miesiąc: } 80 \% \\
\text { 18. miesiąc: } 85 \% \\
\text { 24. miesiąc: } 87 \%\end{array}$ & $\begin{array}{l}\text { 12. miesiąc: } 44 \% \\
\text { 18. miesiąc: } 66 \% \\
\text { 24. miesiąc: } 71 \% \\
\text { 36. miesiąc: } 73 \% \\
\text { 48. miesiąc: } 76 \% \\
\\
\text { 12. miesiąc: } 22 \% \\
\text { 18. miesiąc: } 40 \% \\
\text { 24. miesiąc: } 44 \% \\
\text { 36. miesiąc: } 53 \% \\
\text { 48. miesiąc: } 56 \%\end{array}$ & $\begin{array}{l}\text { 18-miesięczne OS: 98,5\% } \\
\text { 24-miesięczne OS: 97,4\% } \\
\text { 36-miesięczne OS: } 95,1 \% \\
\text { 48-miesięczne OS: } 94,3 \% \\
\text { 48-miesięczne EFS: } 94,5 \% \\
\text { 18-miesięczne OS: } 96,9 \% \\
\text { 24-miesięczne OS: 96,3\% } \\
\text { 36-miesięczne OS: } 94 \% \\
\text { 48-miesięczne OS: 93,3 } \\
\text { 48-miesięczne EFS: 92,6\% }\end{array}$ \\
\hline
\end{tabular}

\footnotetext{
${ }^{a}$ dane $\mathrm{z}$ badania ENESTnd jedynie dla nilotynib $300 \mathrm{mg} 2 \times$ dziennie.
}

ENEST: PFS (przeżycie wolne od progresji) - progresja = faza akceleracji lub kryzy blastycznej, zgon związany z przewlekłą białaczką szpikową w czasie terapii imatynibem/nilotynibem lub w ciągu 30 dni po zakończeniu terapii związanej z badaniem;

MDACC: EFS (przeżycie wolne od zdarzeń) - zdarzenie = progresja do fazy akceleracji lub kryzy blastycznej, utrata większej odpowiedzi cytogenetycznej, oporność/utrata całkowitej odpowiedzi hematologicznej/brak odpowiedzi na leczenie według kryteriów ELN, przerwanie terapii z powodu toksyczności, zgon z każdego powodu lub przerwanie terapii (jeżeli nie liczono wcześniej zgonu jako progresji/zdarzenia); TFS (przeżycie wolne od transformacji) - czas od inicjacji leczenia do progresji choroby do fazy akceleracji/przełomu blastycznego;

OS - przeżycie całkowite.

(2 × 400 mg). Wyniki wykazały większą skuteczność dazatynibu zarówno w zakresie odsetka uzyskiwanych CHR, PCyR i MMR, jak i PFS oraz OS [40]. Większą skuteczność dazatynibu niż IM, wyrażającą się wyższymi odsetkami CHR i CCyR, wykazano także w badaniu START-A oceniającym skuteczność i bezpieczeństwo stosowania dazatynibu u chorych na PBSz w fazie akceleracji opornych lub nietolerujących IM. Po 14 miesiącach obserwacji CHR utrzymało $45 \%$ z badanych osób. Spostrzeżenie to ma dużą wartość praktyczną szczególnie w przypadku chorych, u których stan biologiczny nie pozwala na wykonanie alogenicznej transplantacji komórek hemopoetycznych. Podobnie jak w poprzednim, także w tym badaniu tolerancja dazatynibu była dobra, również u osób z objawami uprzedniej nietolerancji IM [41].

Analiza tolerancji dazatynibu w badaniach START wykazała, że skuteczność dazatynibu stosowanego w dawkach $100 \mathrm{mg} 1 \times, 50 \mathrm{mg} 2 \times, 140 \mathrm{mg} 1 \times$ i $70 \mathrm{mg} 2 \times$ dziennie w fazie przewlekłej jest porównywalna, a dawkowanie $1 \times 100 \mathrm{mg}$ dziennie związane jest $\mathrm{z}$ istotnie mniejszą częstością występowania objawów toksyczności terapii, rzadszą koniecznością redukcji dawki i stosowania przerw w leczeniu [42, 43].

Innym TKI II generacji wprowadzonym do terapii chorych na PBSz jest nilotynib. Wysoką skuteczność i bezpieczeństwo leku u chorych opornych na IM w fazie przewlekłej choroby wykazano po raz pierwszy w 2006 r. [44]. Wyniki badania 2. fazy nad skutecznością i bezpieczeństwem stosowania nilotynibu w dawce $400 \mathrm{mg} 2 \times$ dziennie $\mathrm{u}$ chorych $\mathrm{z}$ niepowodzeniem terapii lub z nietolerancją IM po 4 latach obserwacji wykazały, że 45\% uzyskało CCyR, a szacowane OS i PFS oceniono odpowiednio na $78 \%$ i $57 \%$. Spośród 321 chorych wyjściowo włączonych do próby 98 (31\%) było leczonych przez co najmniej 4 lata. Powodem przerwania stosowania leku były progresja (30\%) lub objawy uboczne (21\%). Nilotynib oceniono jako lek bezpieczny $\mathrm{w}$ grupie odpowiadających chorych $\mathrm{z}$ uprzednio występującymi objawami nietolerancji lub nieskuteczności imatynibu. W badaniu tym potwierdzono także, że nilotynib wykazuje jedynie minimalną krzyżową nietolerancję z IM [45].

\section{Ocena odpowiedzi na leczenie TKI u chorych z PBSz}

Kontrola odpowiedzi na leczenie powinna obejmować ocenę morfologiczną krwi obwodowej, z rozmazem ocenianym metodą mikroskopową, i szpiku kostnego, badanie 
Tabela III - Badania kliniczne oceniające skuteczność terapii pierwszego wyboru za pomocą dazatynibu u chorych w fazie przewleklej przewlekłej bialaczki szpikowej

Table III - Clinical trials evaluating the efficacy of dasatinib as a first line therapy for chronic myeloid leukemia in chronic phase

\begin{tabular}{|c|c|c|c|c|c|}
\hline Badanie/rodzaj & Populacja & Dawka leku & $\begin{array}{c}\text { Całkowite } \\
\text { odpowiedzi } \\
\text { cytogenetyczne } \\
\text { (CCyR) }\end{array}$ & $\begin{array}{l}\text { Odsetek większych } \\
\text { odpowiedzi } \\
\text { molekularnych } \\
\text { (MMR) }\end{array}$ & $\begin{array}{c}\text { Szacowane } \\
\text { EFS, PFS, FFS, TFS i OS }\end{array}$ \\
\hline $\begin{array}{l}\text { MDACC study, [31] } \\
\text { otwarte, } \\
\text { randomizowane, } \\
\text { fazy } 2 \text {. }\end{array}$ & $\begin{array}{l}62 \text { dotychczas nie } \\
\text { leczonych chorych } \\
\text { we wczesnej fazie } \\
\text { przewlekłej }\end{array}$ & $\begin{array}{l}\text { Dazatynib } \\
50 \mathrm{mg} 2 \times \text { dziennie } \\
(\mathrm{n}=31) \\
\text { lub } \\
100 \mathrm{mg} 1 \times \text { dziennie } \\
(\mathrm{n}=31)\end{array}$ & $\begin{array}{l}\text { 3. miesiąc: } 82 \% \\
\text { 6. miesiąc: } 84 \% \\
\text { 12. miesiąc: } 98 \% \\
\text { 18. miesiąc: } 89 \% \\
\text { 24. miesiąc: } 84 \% \\
\text { 30. miesiąc: } 83 \%\end{array}$ & $\begin{array}{l}\text { 3. miesiąc: } 24 \% \\
\text { 6. miesiąc: } 63 \% \\
\text { 12. miesiąc: } 71 \% \\
\text { 18. miesiąc: } 79 \% \\
\text { 24. miesiąc: } 87 \% \\
\text { 30. miesiąc: } 81 \%\end{array}$ & 24-miesięczne EFS: 88\% \\
\hline $\begin{array}{l}\text { S0325 Intergroup } \\
\text { Trial, [32] } \\
\text { otwarte, } \\
\text { randomizowane, } \\
\text { fazy } 2 .\end{array}$ & $\begin{array}{l}253 \text { świeżo } \\
\text { rozpoznanych } \\
\text { chorych w fazie } \\
\text { przewlekłej }\end{array}$ & $\begin{array}{l}\text { Dazatynib } \\
1001 \times \text { dziennie } \\
(\mathrm{n}=123)\end{array}$ & 12. miesiąc: $82 \%$ & $\begin{array}{l}\text { 12. miesiąc: redukcja } \\
\text { ilości transkryptu } \\
\text { BCR-ABL >3 log: 59\% } \\
\text { 12. miesiąc: } \\
\text { redukcja ilości } \\
\text { transkryptu } \\
\text { BCR-ABL > } 4 \text { log: } 27 \% \\
\text { 12. miesiąc: redukcja } \\
\text { ilości transkryptu } \\
\text { BCR-ABL >3 log: } 43 \% \\
\text { 12. miesiąc: } \\
\text { redukcja ilości } \\
\text { transkryptu } \\
\text { BCR-ABL > } 4 \text { log: } 20 \%\end{array}$ & $\begin{array}{l}\text { 12-miesięczne PFS: 99\% } \\
\text { 12-miesięczne OS: 100\% }\end{array}$ \\
\hline $\begin{array}{l}\text { DASISION study, } \\
\text { [34-36], otwarte, } \\
\text { randomizowane, } \\
\text { fazy } 3 .\end{array}$ & $\begin{array}{l}519 \text { świeżo } \\
\text { zdiagnozowanych } \\
\text { chorych } \\
\text { we wczesnej } \\
\text { fazie przewlekłej }\end{array}$ & $\begin{array}{l}\text { Imatynib } \\
400 \mathrm{mg} 1 \times \text { dziennie } \\
(\mathrm{n}=260)\end{array}$ & $\begin{array}{l}\text { 3. miesiąc: } 54 \% \\
\text { 6. miesiąc: } 73 \% \\
\text { 9. miesiąc: } 78 \% \\
\text { 12. miesiąc: } 77 \% \\
\text { 18. miesiąc: } 78 \% \\
\text { 24. miesiąc: } 86 \% \\
\text { 3. miesiąc: } 31 \% \\
\text { 6. miesiąc: } 59 \% \\
\text { 9. miesiąc: } 67 \% \\
\text { 12. miesiąc: } 66 \% \\
\text { 18. miesiąc: } 70 \% \\
\text { 24. miesiąc: } 82 \%\end{array}$ & $\begin{array}{l}\text { 3. miesiąc: } 8 \% \\
\text { 6. miesiąc: } 27 \% \\
\text { 9. miesiąc: } 39 \% \\
\text { 12. miesiąc: } 46 \% \\
\text { 24. miesiąc: } 63 \% \\
\\
\text { 3. miesiąc: } 0,4 \% \\
\text { 6. miesiąc: } 8 \% \\
\text { 9. miesiąc: } 18 \% \\
\text { 12. miesiąc: } 28 \% \\
\text { 24. miesiąc: } 46 \%\end{array}$ & $\begin{array}{l}\text { 12-miesięczne PFS: 97\% } \\
\text { 12-miesięczne PFS: } 94 \% \\
\text { 12-miesięczne OS: } 99 \% \\
\text { 18-miesięczne OS: } 98 \%\end{array}$ \\
\hline
\end{tabular}

DASISION: PFS jak EFS w badaniu IRIS - zdarzenie = progresja do fazy akceleracji lub kryzy blastycznej w czasie terapii imatynibem, zgon z każdego powodu w czasie terapii imatynibem, utrata całkowitej odpowiedzi hematologicznej (CHR) lub większej odpowiedzi cytogenetycznej (MCyR), a ponadto wzrost liczby leukocytów powyżej $20 \times 109$ G/L, zgon z każdego powodu w czasie terapii dazatynibem/imatynibem lub w ciągu 60 dni po zakończeniu terapii zaplanowanej w badaniu;

MDACC: EFS - oceniano od chwili inicjacji terapii do wystąpienia następujących zdarzeń: zgonu z jakiejkolwiek przyczyny, utraty całkowitej odpowiedzi hematologicznej, utraty całkowitej odpowiedzi cytogenetycznej, przerwania terapii z powodu toksyczności lub wykazania nieskuteczności leku lub progresji do fazy akceleracji przełomu blastycznego;

S0325: PFS - od daty randomizacji do progresji PBSz do fazy akceleracji/przełomu blastycznego; wznowy po uzyskaniu całkowitej odpowiedzi ematologicznej lub zgonu z jakiejkolwiek przyczyny, obserwację kończono na dacie ostatniego kontaktu z pacjentem potwierdzającego, że żyje bez cech progresji lub wznowy.

cytogenetyczne, a także molekularne typu i liczby kopii transkryptu genu $B C R / A B L$ oraz w wybranych przypadkach badanie obecności mutacji domeny genu ABL. Od momentu rozpoczęcia leczenia TKI badania morfologii krwi obwodowej z rozmazem powinny być wykonywane przynajmniej raz na 2 tygodnie do potwierdzenia uzyskania CHR, a następnie przynajmniej co 3 miesiące i w razie wskazań (Tab. IV). Punkcja szpiku w chwili diagnozy PBSz jest niezbędna, gdyż dostarcza materiału do oceny cytologicznej oraz badania kariotypu. Należy także rozważyć wykonanie trepanobiopsji szpiku w chwili ustalania diagnozy, gdyż może dostarczyć dodatkowych informacji na temat obecności skupisk komórek blastycznych, obecności włóknienia retikulinowego, neoangiogenezy lub cech dysplazji. W przypadku rozpoznania PBSz $\mathrm{w}$ fazie kryzy blastycznej jej różnicowania na typ limfo- lub mieloblastyczny, erytroblastyczny lub megakarioblastyczny należy dokonać w oparciu o immunofenotypizację lub/i badanie immunohistochemiczne. Badanie pełnego kariotypu metodami konwencjonalnej cytogenetyki (metodą analizy prążków GTG) komórek szpiku pobranego drogą biopsji aspiracyjnej powinno być wykonane w chwili rozpoznania, po 3 miesiącach od rozpoczęcia leczenia TKI, gdy poziom transkryptu genu $B C R / A B L \geq 10 \%$ [IS], następnie po 6 miesiącach, gdy poziom transkryptu genu $B C R / A B L \geq 1 \%$ [IS], po 12 miesiącach, a następnie w razie uzyskania CCyR co 12 miesięcy, jeśli 
Tabela IV - Rekomendacje dotyczące badań laboratoryjnych oceniających skuteczność leczenia inhibitorami kinaz tyrozynowych (TKI)

Table IV - Recommendations for diagnostic tests evaluating the response to TKI

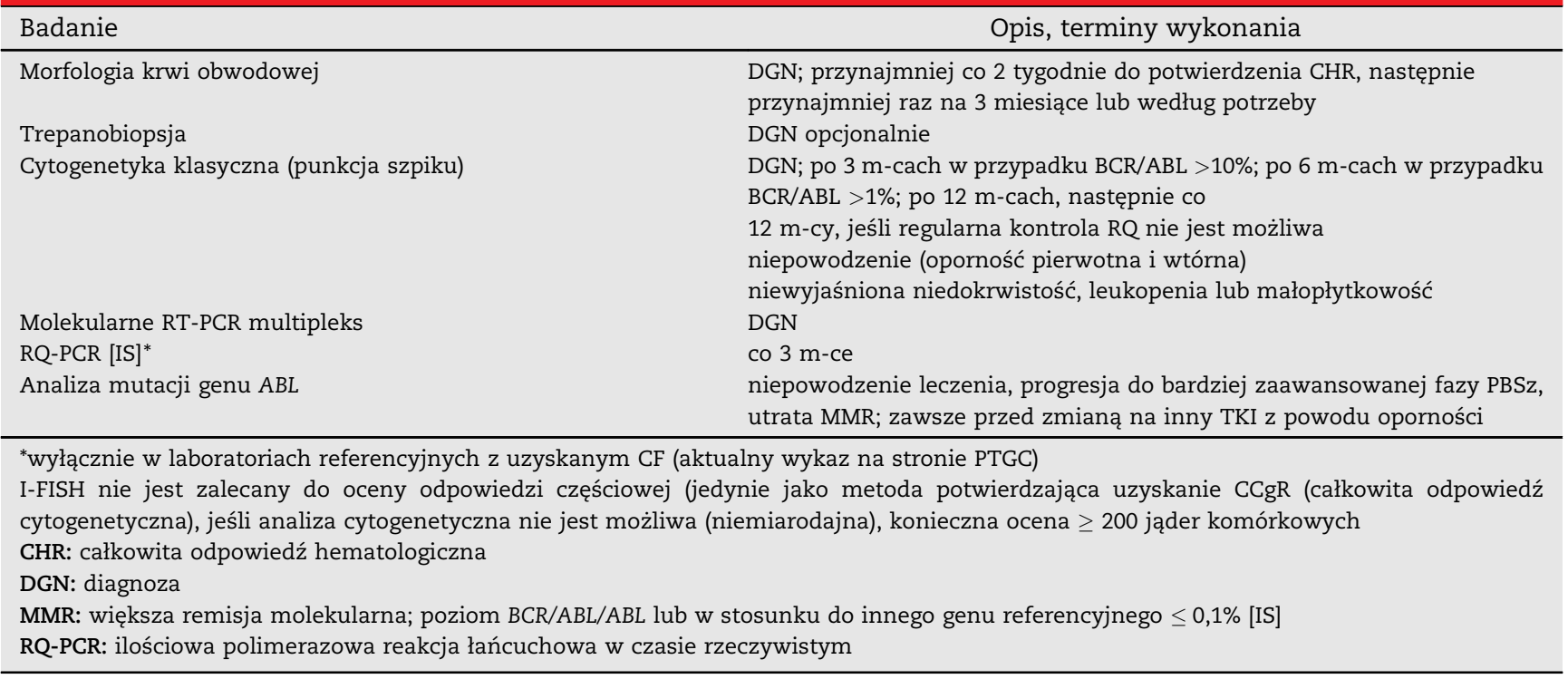

regularna kontrola przebiegu leczenia za pomocą wystandaryzowanej zgodnie z zaleceniami ELN ilościowej polimerazowej reakcji łańcuchowej w czasie rzeczywistym (RQPCR; Real Time Quantitative Polymerase Chain Reaction) nie jest możliwa. Badanie cytogenetyczne powinno być także wykonane w każdym przypadku niepowodzenia leczenia (oporność pierwotna lub wtórna) oraz w razie pojawienia się niedokrwistości, leukopenii lub małopłytkowości o trudnej do ustalenia przyczynie (Tab. IV). Miarodajna ocena kariotypu wymaga analizy przynajmniej 30 komórek zatrzymanych $\mathrm{w}$ metafazie. Jeżeli nie ma możliwości uzyskania odpowiedniej jakości materiału do oceny cytogenetycznej i wynik badania konwencjonalnej cytogenetyki nie jest dostępny, w celu potwierdzenia rozpoznania lub potwierdzenia uzyskania CCyR dopuszczalne jest zastosowanie metody fluorescencyjnej interfazalnej hybrydyzacji in situ (I-FISH) z zastrzeżeniem, że nie jest to odpowiednia metoda oceny jakości odpowiedzi cytogenetycznej (od minimalnej do częściowej). Wymagana jest ocena przynajmniej 200 jąder interfazowych [46]. Do identyfikacji typu transkryptu genu BCR/ABL w chwili diagnozy służy badanie krwi obwodowej metodą polimerazowej reakcji łańcuchowej poprzedzonej odwrotną transkrypcją (RT-PCR; Reverse Transcription Polymerase Chain Reaction) w odmianie multipleks. Śledzenie dynamiki odpowiedzi molekularnej u chorych leczonych TKI jest możliwe dzięki wykonywaniu ilościowego badania RQ-PCR (Tab. IV). Badanie RQ-PCR powinno być wykonywane przed podjęciem leczenia TKI, potem co 3 miesiące do uzyskania MMR, a następnie nie rzadziej niż co 6 miesięcy. Utrata MMR albo wzrost liczby kopii transkrytpu (1 logarytm w skali IS) genu BCR/ABL jest wskazaniem do zwiększenia częstotliwości wykonywania oznaczeń RQ-PCR [46]. W celu upewnienia się, że obserwowany wzrost jest wyrazem rzeczywistej tendencji, test należy powtórzyć (najlepiej w odstępie 1 miesiąca). Częstszego monitorowania molekularnego mogą wymagać pacjenci $\mathrm{w}$ fazie przewlekłej $\mathrm{z}$ niepowodzeniem uprzedniego leczenia za pomocą TKI, z utratą uprzednio uzyskanej CHR, CCyR, MMR, z progresją do AP lub BC oraz chorzy leczeni inhibitorami TKI II generacji (ze względu na szybciej uzyskiwane odpowiedzi). Ze względu na wysoki stopień skomplikowania RQ-PCR, czułość dochodzącą do

Tabela V - Lista referencyjnych laboratoriów diagnostyki molekularnej standaryzowanych zgodnie z ELN, które uzyskaly indywidualny wskaźnik korygujący CF Table V - Reference laboratories with individual correction factor calculated according to ELN guidelines

\begin{tabular}{|c|c|}
\hline Lp & Nazwa Laboratorium \\
\hline 1. & Katedra i Zakład Genetyki Klinicznej CMUMK w Bydgoszczy \\
\hline 2. & $\begin{array}{l}\text { Pracownia Diagnostyki Molekularnej Gdański Uniwersytet } \\
\text { Medyczny Katedra i Klinika Hematologii i Transplantologii } \\
\text { w Gdańsku }\end{array}$ \\
\hline 3. & $\begin{array}{l}\text { Pracownia Biologii Molekularnej w Laboratorium Hemato- } \\
\text { logicznym, Pracownia Inżynierii Szpiku i Banku Komórek } \\
\text { Klinika Hematologii i Transplantacji Szpiku w Katowicach }\end{array}$ \\
\hline 4. & $\begin{array}{l}\text { Pracownia Diagnostyki Molekularnej Centrum Onkologii } \\
\text { w Kielcach }\end{array}$ \\
\hline 5. & $\begin{array}{l}\text { Pracownia Diagnostyki Molekularnej Katedry i Kliniki } \\
\text { Hematologii Collegium Medicum Uniwersytetu Jagielloń- } \\
\text { skiego w Krakowie }\end{array}$ \\
\hline 6. & $\begin{array}{l}\text { Pracownia Biologii Molekularnej Klinika Hematologii } \\
\text { i Transplantacji Szpiku UM w Poznaniu }\end{array}$ \\
\hline 7. & $\begin{array}{l}\text { Pracownia Genetyki, Zakład Diagnostyki Hematologicznej, } \\
\text { Instytut Hematologii i Transfuzjologii w Warszawie }\end{array}$ \\
\hline 8. & $\begin{array}{l}\text { Pracownia Biologii Molekularnej, Specjalistyczne Labora- } \\
\text { torium Diagnostyki Hematologicznej i Transplantacyjnej, } \\
\text { Szpital Kliniczny nr } 1 \text { we Wrocławiu }\end{array}$ \\
\hline 9. & $\begin{array}{l}\text { Pracownia Genetyki Dolnośląskiego Centrum Transplan- } \\
\text { tacji Komórkowych z Krajowym Bankiem Dawców Szpiku } \\
\text { we Wrocławiu }\end{array}$ \\
\hline 10. & $\begin{array}{l}\text { Samodzielna Pracownia Hematoonkologii Doświadczalnej, } \\
\text { Uniwersytet Medyczny w Lublinie }\end{array}$ \\
\hline
\end{tabular}


$10^{-5}-10^{-6}$ i duże ryzyko powstania nieprawidłowości $\mathrm{w}$ przebiegu procedury laboratoryjnej, wymogiem jest, aby badania te wykonywane były $\mathrm{z}$ zachowaniem standardów i zaleceń sformułowanych $\mathrm{w}$ toku procesu standaryzacji prowadzonej przez European Leukemia Net (ELN). W celu uzyskania miarodajnych wyników i uniknięcia popełnienia poważnych błędów mogących skutkować podjęciem niewłaściwych decyzji terapeutycznych testy molekularne powinny być wykonywane wyłącznie w laboratoriach poddanych standaryzacji i regularnej kontroli w ramach procedury organizowanej przez ELN (Tab. V). W ich wyniku każde z uczestniczących laboratoriów uzyskuje indywidualny wskaźnik korygujący (CF; conversion factor) umożliwiający wydawanie wyników w skali międzynarodowej (IS; international scale). Zaleca się, aby wynik wydawany był zgodnie ze standardem opracowanym przez ELN i obejmował, między innymi: liczbę kopii transkryptu BCR/ABL wyrażoną w skali międzynarodowej (powinien być oflagowany symbolem IS), liczbę kopii genu referencyjnego oraz informację o czułości osiągniętej w tym konkretnym oznaczeniu (wymagana minimalna czułość testu to $10^{-4}$ ) (Ryc. 1). Zalecanymi wskazaniami do badania mutacji genu $A B L$ są: niepowodzenie leczenia, progresja do bardziej zaawansowanej fazy PBSz, utrata MMR, konieczność zmiany na inny TKI z powodu oporności lub konieczność wdrożenia leczenia innego typu [46]. Metodą, którą aktualnie wykorzystuje się w celu wykrywania mutacji domeny kinazy ABL, jest bezpośrednie sekwencjonowanie o czułości $10-25 \%$. W badaniu przesiewowym stosowana jest niekiedy wysokosprawna chromatografia cieczowa (D-HPLC; denaturing high-performance liquid chromatography) (czułość 1-10\%) [47-49]. Inne metody wykrywają specyficznie niewielkie klony zmutowanych komórek z dużo większą czułością, jednak znaczenie ich wykrywania dla dalszego przebiegu leczenia pozostaje nadal w sferze badań.

\section{Znaczenie prognostyczne uzyskania wczesnej głębokiej odpowiedzi molekularnej}

Szybka redukcja ilości komórek białaczkowych (BCR/ABL dodatnich) w krótkim czasie od rozpoczęcia leczenia za pomocą TKI wpływa korzystnie na wyniki odległe prowadzonej terapii [50-54]. Szczegółowa analiza korzyści potwierdziła związek pomiędzy szybką redukcją liczby kopii transkryptu BCR/ABL z dłuższym czasem trwania EFS, PFS i OS. Wykazano bowiem, że u pacjentów, u których po 3 miesiącach leczenia za pomocą IM doszło do redukcji liczby kopii transkryptu genu $B C R / A B L \leq 10 \%$, a po 6 miesiącach $\leq 1 \%$, odsetek 8-letnich EFS, PFS i OS jest znamiennie wyższy niż $\mathrm{u}$ chorych bez takiej redukcji [53]. Podobnie osiągnięcie w 3. miesiącu leczenia IM przynajmniej PCyR korespondującej z redukcją poziomu BCR/ABL $\leq 10 \%$ i CCyR po 6 miesiącach (odpowiada redukcji $B C R / A B L \leq 1 \%$ ) w badaniu $C M L$ German Study IV wiązało się z istotnie większym odsetkiem uzyskanych 5-letnich PFS i OS [55, 56]. Podobne wyniki uzyskano w badaniach porównujących skuteczność imatynibu i TKI II generacji stosowanych w terapii pierwszej linii. W badaniu ENESTnd skumulowane odsetki MMR i $\mathrm{MR}^{4.5}$ po 2 latach leczenia nilotynibem lub IM różniły się istotnie statystycznie w zależności od stopnia uzyskanej redukcji ilości kopii transkryptu BCR/ABL po pierwszych 3 miesiącach terapii. Należy podkreślić, że odsetek chorych uzyskujących większą redukcję poziomu transkryptu ( $\leq 10 \%$ oraz $\leq 1 \%$ ) $\mathrm{w}$ trakcie leczenia nilotynibem był istotnie statystycznie większy niż w grupie otrzymujących IM i wyniósł odpowiednio $90,7 \%$ us $66,7 \%$ oraz $56,2 \%$ us $16,3 \%$ [57]. Odsetek PFS po 48 miesiącach leczenia nilotynibem w zależności od redukcji poziomu transkryptu w 3 . miesiącu terapii do $\leq 10 \%$ lub $>10 \%$ wyniósł odpowiednio $95,2 \%$ i $82,9 \%$, a odsetek OS w tych grupach pacjentów oceniono odpowiednio na $96,7 \%$ i $86,7 \%$ (różnice istotne statystycznie). Wśród pacjentów z transkryptem $B C R / A B L>10 \%$ po pierwszych 3 miesiącach leczenia znamiennie większe szanse na redukcję poziomu transkryptu do $\leq 10 \%$ po kolejnych 3 miesiącach leczenia mieli pacjenci otrzymujący nilotynib (79,2\%) niż chorzy leczeni IM (54,5\%). U chorych otrzymujących IM częściej dochodziło także do progresji choroby (15,9\% us $8,3 \%$ ). Podobne obserwacje poczyniono $\mathrm{w}$ badaniu DASISION, w którym wykazano, że skumulowana częstość $\mathrm{MR}^{4.5}$ po 3 latach leczenia dazatynibem w zależności od redukcji poziomu transkryptu po 3 miesiącach terapii była znacząco wyższa u pacjentów leczonych dazatynibem niż imatynibem [58]. Odsetki PFS po 36 miesiącach leczenia dazatynibem w zależności od redukcji poziomu transkryptu w 3 miesiącu terapii do $\leq 10 \%$ lub $>10 \%$ wynosiły odpowiednio $94 \%$ i $68,2 \%$. Także OS w tych grupach pacjentów było znacząco lepsze u pacjentów otrzymujących dazatynib (odpowiednio $96,5 \%$ i $85,9 \%)$. Opisane prawidłowości występują niezależnie od przyjmowanego TKI, jednak głęboką odpowiedź molekularną znamiennie częściej uzyskują chorzy otrzymujący TKI II generacji. Redukcję poziomu transkrytpu do $\leq 10 \%$ i do $\leq 1 \%$ w 3. miesiącu terapii uzyskało odpowiednio $90,7 \%$ i $56,2 \%$ chorych leczonych nilotynibem (ENESTnd) i $84 \%$ oraz $48 \%$ pacjentów otrzymujących dazatynib (DASISION). Odsetek chorych, którzy uzyskali taki poziom redukcji liczby kopii transkryptu pod wpływem IM, był w obu badaniach istotnie statystycznie niższy i wyniósł odpowiednio 66,7\% i 16,3\% (ENESTnd) oraz 64\% i 13\% (DASISION). Do podobnych wniosków doprowadziły badania oceniające znaczenie uzyskania redukcji poziomu transkryptu genu BCR/ABL w 6. miesiącu leczenia TKI. Okazało się, że odsetek PFS i OS po 3 latach obserwacji był znacząco wyższy u chorych $\mathrm{z}$ redukcją poziomu transkryptu do $\leq 10 \%$ (w badaniu DASISION odpowiednio PFS: $90,7 \%$ us $66,2 \%$ i OS: $97,8 \%$ us $84 \%$ ). Stwierdzono ponadto, że chorzy $\mathrm{z}$ poziomem transkryptu $>10 \%$ w 6 . miesiącu terapii TKI mają istotnie większe ryzyko transformacji do bardziej zaawansowanych faz PBSz [58]. Powyższe rezultaty wskazują, że osiągnięcie redukcji poziomu transkryptu genu $B C R / A B L$ do $\leq 1 \%$ $\mathrm{w}$ ciągu pierwszych 3 miesięcy leczenia TKI wiąże się $\mathrm{z}$ istotnie większą szansą na osiągnięcie $M M R, \mathrm{MR}^{4} \mathrm{i} \mathrm{MR}^{4,5}$ $\mathrm{w}$ toku dalszego leczenia, a redukcja do $\leq 10 \%$ definiuje grupę chorych dobrego rokowania odnośnie do EFS, PFS i OS. Grupę pacjentów z poziomem transkryptu >10\% w 3 . miesiącu leczenia TKI charakteryzuje nie tylko mniejszy odsetek uzyskiwanych EFS, PFS i OS, ale także zwiększone ryzyko transformacji do fazy akceleracji lub kryzy blastycznej. Wykazano bowiem, że dochodzi do niej u 8,3\% chorych otrzymujących nilotynib (ENESTnd), u 13,5\% chorych otrzymujących dazatynib (DASISION) i u 15,9\% i 12,9\% leczonych 
Pracownia

Imię i Nazwisko pacjenta: Data przyjęcia materialu: Material:

Badanie: Nr. księgi
PESEL:

Krew obwodowa Lekarz kierujący:

Kontrolne

\begin{tabular}{|c|c|c|c|c|c|}
\hline $\begin{array}{c}\text { Typ } \\
\text { transkryptu }\end{array}$ & $\begin{array}{c}\text { Liczba kopii } \\
\text { BCR/ABL }\end{array}$ & $\begin{array}{c}\text { Liczba kopii } \\
\text { genu kontrolnego } \\
\text { (ABL) }\end{array}$ & $\begin{array}{c}\text { Stosunek } \\
{[\% \text { \} }}\end{array}$ & $\begin{array}{c}\text { Liczba wyrażona } \\
\text { w skali } \\
\text { międzynarodowej } \\
{[\text { SI] }}\end{array}$ & $\begin{array}{c}\text { Czułośćć } \\
\text { testu }\end{array}$ \\
\hline b3a2 & 28,9 & 34344,5 & 0,08 & $\mathbf{0 , 0 4}$ & $\mathbf{1 0}^{-5}$ \\
\hline
\end{tabular}

* Pracownia.............wzięła udział w standaryzacji badan RQ-PCR dotyczącej monitorowania kinetyki genu $B C R / A B L$ w PBSz w ramach programu European Leukemia Net. Ustalono indywidualny wskaźnik korygujący $(\mathrm{CF}=\ldots \ldots)$.

Konsultacja:

Data wydania wyniku:

Wykonat:

Zatwierdził:

Ryc. 1 - Przykład wzoru wyniku badania RQ-PCR wydanego przez standaryzowaną zgodnie z European Leukemia Net Pracownię Biologii Molekularnej

Fig. 1 - Example of RQ-PCR report template issued by Molecular Biology Laboratory standardized according to European Leukemia Net guidelines

IM (odpowiednio w badaniu ENESTnd oraz DASISION). Przytoczone dane wykazują przydatność oceny za pomocą RQ-PCR w 3. miesiącu terapii TKI. Wynik tego badania powinien stać się przesłanką do rozważenia decyzji o modyfikacji stosowanego leczenia, tak aby końcowy wynik terapii pozwolił osiągnąć założone cele.

\section{Leczenie pierwszej linii PBSz w fazie przewlekłej}

Aktualne rekomendacje dotyczące terapii pierwszej linii oraz definicji poszczególnych kategorii odpowiedzi na leczenie opierają się na wynikach dobrze udokumentowanych badań klinicznych. Potwierdzono w nich, że rokowanie w grupie pacjentów osiągających w trakcie leczenia pierwszej linii jedynie odpowiedź suboptymalną, według propozycji ELN, jest istotnie gorsze $\mathrm{w}$ porównaniu $\mathrm{z}$ osobami odpowiadającymi optymalnie [59-61]. Co więcej, jest ono równie niekorzystne jak $\mathrm{u}$ chorych $\mathrm{z}$ niepowodzeniem leczenia [62]. Kolejnym istotnym spostrzeżeniem było stwierdzenie, że jak najszybsze osiągnięcie głębokiej odpowiedzi molekularnej ma istotne znaczenie dla dalszych losów pacjenta. Potwierdzono bowiem, że redukcja poziomu transkryptu BCR/ABL $\mathrm{w}$ pierwszych trzech miesiącach leczenia do wartości $\leq 10 \%$ jest powiązana $z$ istotnie większą szansą uzyskania MMR,
$\mathrm{MR}^{4}$ i MR ${ }^{4,5}$ oraz korzystnego EFS, PFS i OS [51-53, 55, 56, 58]. $\mathrm{Na}$ podstawie powyższych ustaleń sformułowano nowe kryterium odpowiedzi optymalnej po 3 miesiącach leczenia pierwszego rzutu opierające się na wyniku badania RQ-PCR (Tab. VI). W przypadku gdy BCR/ABL w tym punkcie oceny wynosić będzie $\geq 10 \%$, należy wykonać dodatkowo badanie cytogenetyczne, a takżę analizę obecności mutacji domeny kinazowej ABL. Zalecono także, aby rozpoznanie niepowodzenia terapii poprzedzone było dodatkową oceną liczby kopii BCR/ABL wykonaną po 4 tygodniach od zlecenia wykonania pierwszego badania. W przypadku rozpoznania niepowodzenia terapii na podstawie wyniku dwóch niezależnych testów (badanie cytogenetyczne, molekularne) ponowne ich wykonanie nie jest wymagane (Tab. VI). Pacjenci, którzy uzyskują odpowiedź molekularną z poziomem BCR/ $A B L \leq 1 \%$ w 3 . miesiącu leczenia TKI oraz głęboką odpowiedź molekularną ( $B C R / A B L \leq 0,01 \%)$ potwierdzoną testem jakościowym lub ilościowym PCR o czułości przynajmniej $10^{-4,5}$, w toku dalszego leczenia stanowią grupę chorych o najlepszym rokowaniu.

W leczeniu 1. linii PBSz w fazie przewlekłej rekomendowane jest stosowanie imatynibu w dawce $400 \mathrm{mg} / \mathrm{d}$ lub dazatynibu w jednorazowej dawce dobowej $100 \mathrm{mg} / \mathrm{d}$ albo nilotynibu w dawce $2 \times 300 \mathrm{mg} / \mathrm{d}$. Wybrany sposób terapii należy kontynuować do momentu pojawienia się oporności 
Tabela VI - Ocena odpowiedzi na leczenie PBSz inhibitorami kinaz tyrozynowych

Table VI - Evaluation of overall response to tyrosine kinase inhibitors

Czas oceny (miesiąc)

ODPOWIEDŹ

\begin{tabular}{|c|c|c|c|}
\hline & \\
\hline & optymalna & niepowodzenie & ostrzeżenie \\
\hline przy rozpoznaniu & & & $\begin{array}{l}\text { dodatkowe zaburzenia } \\
\text { cytogenetyczne w kom } \mathrm{Ph}(+)\end{array}$ \\
\hline 3. & $\begin{array}{l}\text { BCR/ABL }[\text { IS }]<10 \% \\
\text { lub co najmniej } \\
\text { Ph+ } \leq 35 \% \text { w badaniu } \\
\text { cytogenetycznym }\end{array}$ & $\begin{array}{l}\text { BCR/ABL }[\mathrm{IS}] \geq 10 \% \\
\text { i Ph+ }>35 \% \text { w badaniu } \\
\text { cytogenetycznym }\end{array}$ & $\mathrm{BCR} / \mathrm{ABL}[\mathrm{IS}] \geq 1 \%$ \\
\hline 6. & $\begin{array}{l}\text { BCR/ABL }[\mathrm{IS}]<1 \% \\
\text { lub } \mathrm{Ph}+0 \% \mathrm{w} \text { badaniu } \\
\text { cytogenetycznym }\end{array}$ & $\begin{array}{l}\text { BCR/ABL }[\mathrm{IS}] \geq 1 \% \\
\text { i } \mathrm{Ph}+>0 \% \text { w badaniu } \\
\text { cytogenetycznym }\end{array}$ & \\
\hline $\begin{array}{l}12 . \\
\text { kiedykolwiek w trakcie leczenia }\end{array}$ & $\begin{array}{l}\text { BCR/ABL }[\mathrm{IS}] \leq 0,1 \% \\
\text { stały spadek liczby } \\
\text { transkryptu BCR/ABL }\end{array}$ & $\begin{array}{l}\text { BCR/ABL }[\mathrm{IS}]>0,1 \% \\
\text { utrata CHR, CCyR, } \\
\text { MMR, nowa mutacja } \\
\text { ABL, dodatkowe zaburzenia } \\
\text { cytogenetyczne } \\
\text { w komórkach } \mathrm{Ph}(+)\end{array}$ & $\begin{array}{l}\text { brak spadku poziomu } \\
\text { transkryptu }\end{array}$ \\
\hline
\end{tabular}

" Rozpoznanie niepowodzenia w oparciu o jeden test wymaga potwierdzenia w kolejnym oznaczeniu w ciągu 4 tygodni. W przypadku rozpoznania niepowodzenia w dwóch niezależnych testach nie wymaga się ponownego potwierdzenia dodatkowym badaniem.

" Do zaburzeń, które w chwili rozpoznania pogarszają rokowanie, należą: +8 , Ph+, iso(17q), +19. Stanowią ostrzeżenie, jeśli zostały wykryte w przynajmniej dwóch komórkach $\mathrm{Ph}(+)$.

-W przypadku gdy BCR/ABL $\geq 10 \%$ należy wykonać badanie cytogenetyczne i w kierunku obecności mutacji genu ABL. Pacjenci, którzy uzyskują odpowiedź molekularną z poziomem BCR/ABL $\leq 1 \%$ po pierwszych 3 miesiącach leczenia TKI oraz głęboką odpowiedź molekularną (BCR/ABL $\leq 0,01 \%$ ) potwierdzoną testem jakościowym lub ilościowym PCR o czułości przynajmniej $10^{-4,5} \mathrm{w}$ toku dalszego leczenia stanowią grupę chorych o najlepszym rokowaniu. Sa to potencjalni kandydaci do badań klinicznych nad możliwością odstawienia IKT, mający najwieksze szanse na uzyskanie długotrwałego przeżycia wolnego od leczenia. Jeżeli przyczyną niepowodzenia jest redukcja poziomu transkryptu po pierwszych 3 miesiącach do $\geq 10 \%$, zmiany leczenia należy dokonać po potwierdzeniu tego wyniku, najpóźniej w 6 . miesiącu terapii.

lub objawów nietolerancji terapii. Biorąc pod uwagę dane o większej skuteczności TKI II generacji w leczeniu 1. linii, zawsze należy rozważyć możliwość zastosowania najbardziej skutecznej formy leczenia już od momentu rozpoznania PBSz (Tab. VI). Leczenie za pomocą hydroksymocznika jest dopuszczalne jedynie przez krótki czas, a także u chorych, u których leczenie TKI nie jest zalecane. Nie ma konieczności stosowania hydroksymocznika przed wdrożeniem TKI w celu redukcji wysokiej leukocytozy w chwili rozpoznania PBSz. Podawanie interferonu $\alpha$ jest opcją leczenia kobiet w ciąży z PBSz. Lek ten należy także stosować w okresie koncepcji oraz podczas karmienia (vide leczenie kobiet w ciąży). Możliwe jest również zastosowanie interferonu $\alpha \mathrm{u}$ pacjentów niskiego ryzyka niepomyślnego przebiegu PBSz, u których zastosowanie TKI z powodu współwystępowania schorzeń dodatkowych lub przyjmowania innych leków nie jest zalecane [46]. Leczenie TKI powinno zostać wdrożone jak najwcześniej tuż po rozpoznaniu PBSz. Doświadczenia własne wskazują bowiem, że rozpoczęcie leczenia po upływie 6 miesięcy od rozpoznania wiąże się ze zmniejszoną szansą uzyskania CCyR w 12. i MMR $\mathrm{w}$ 18. miesiącu leczenia oraz $\mathrm{MR}^{4} \mathrm{w}$ trakcie całego okresu leczenia IM [63].

\section{Leczenie pacjentów $\mathbf{z}$ opornością/nietolerancją} 1. linii terapii imatynibem $\mathrm{w}$ dawce $400 \mathrm{mg} / \mathrm{d}$

Pierwotną oporność na leczenie TKI należy rozpoznać u chorych, którzy po określonym czasie trwania terapii nie uzyskują określonego typu odpowiedzi na leczenie (Tab. VI). Oporność wtórna dotyczy pacjentów, u których dochodzi do utraty wcześniej uzyskanej odpowiedzi w dowolnym momencie prowadzonego leczenia. Stwierdzenie oporności jest równoznaczne $\mathrm{z}$ niepowodzeniem leczenia i wymaga zmiany sposobu prowadzenia terapii (Tab. VI).

Zdecydowana większość pacjentów dobrze toleruje leczenie IM i pozostałymi TKI, a działania uboczne najczęściej są słabo wyrażone, łatwe do opanowania leczeniem objawowym i najczęściej nie powodują konieczności zmiany stosowanego leczenia. Należy jednak podkreślić, że ich występowanie może istotnie wpływać na skuteczność prowadzonej terapii, a u niewielkiego odsetka chorych być przyczyną odstawienia leku z powodu jego nietolerancji. Jedna $\mathrm{z}$ definicji nietolerancji leczenia za pomocą TKI obejmuje wystąpienie przynajmniej jednego spośród poniższych zdarzeń: jakakolwiek zagrażająca życiu toksyczność niehematologiczna stopnia 4., nawrót jakiejkolwiek toksyczności niehematologicznej stopnia 3. lub 4. pomimo redukcji dawki stosowanego TKI i adekwatnego leczenia objawów niepożądanych, wystąpienie jakiejkolwiek toksyczności niehematologicznej stopnia 2. utrzymującej się dłużej niż 1 miesiąc pomimo stosowania optymalnego leczenia wspomagającego, wystąpienie toksyczności hematologicznej stopnia 3. lub 4. nieodpowiadającej na leczenie wspomagające i wymagającej redukcji dawki do poziomu poniżej minimalnej akceptowalnej dawki skutecznej [64]. Należy pamiętać, że podczas wieloletniego stosowania leku wystąpienie działań niepożądanych już w 2. czy nawet 1. stopniu toksyczności może być przyczyną nieprzestrzegania zaleceń dotyczących przyjmowania TKI, a przez to negatywnie wpływać na skuteczność leczenia. Dlatego, w przypadku stwierdzenia oporności na TKI, należy zawsze sprawdzić stopień przestrzegania zaleceń przez pacjenta (adherence, compliance). Po 
Tabela VII - Zalecenia terapii PBSz w fazie przewleklej

Table VII - Treatment recommendations for CML in chronic phase

\begin{tabular}{|c|c|}
\hline Typ/faza choroby & Rekomendacja \\
\hline \multicolumn{2}{|l|}{ Leczenie pierwszej linii } \\
\hline Wszyscy pacjenci & imatynib $400 \mathrm{mg} / \mathrm{d}$ lub dazatynib $100 \mathrm{mg} / \mathrm{d}$ albo nilotynib $2 \times 300 \mathrm{mg} / \mathrm{d}$ \\
\hline \multicolumn{2}{|l|}{ Leczenie drugiej linii } \\
\hline \multicolumn{2}{|l|}{ Nietolerancja lub niepowodzenie:" } \\
\hline - Imatynibu & dazatynib 100 mg/d lub nilotynib $2 \times 400$ mg/d, albo bozutynib 500 mg/d \\
\hline - Dazatynibu & Nilotynib $2 \times 400 \mathrm{mg} / \mathrm{d}$ lub bozutynib $500 \mathrm{mg} / \mathrm{d}$ \\
\hline - Nilotynibu & dazatynib $100 \mathrm{mg} / \mathrm{d}$ lub bozutynib $500 \mathrm{mg} / \mathrm{d}$ \\
\hline Niepowodzenie - wszyscy pacjenci & $\begin{array}{l}\text { allo-HCT u chorych z progresją do fazy akceleracji albo kryzy blastycznej, } \\
\text { lub z mutacją T315i }\end{array}$ \\
\hline \multicolumn{2}{|l|}{ Leczenie trzeciej linii } \\
\hline \multicolumn{2}{|l|}{ Nietolerancja lub niepowodzenie:" } \\
\hline - Dazatynibu & Nilotynib $2 \times 400 \mathrm{mg} / \mathrm{d}$, lub bozutynib $500 \mathrm{mg} / \mathrm{d}$ \\
\hline - Nilotynibu & dazatynib $100 \mathrm{mg} / \mathrm{d}$, lub bozutynib $500 \mathrm{mg} / \mathrm{d}$ \\
\hline - Bozutynibu & dazatynib $100 \mathrm{mg} / \mathrm{d}$ lub nilotynib $2 \times 400 \mathrm{mg} / \mathrm{d}$ \\
\hline Niepowodzenie - wszyscy pacjenci & allo-HCT* \\
\hline \multicolumn{2}{|c|}{$\begin{array}{l}\text { U chorych niekwalifikujących się do allo-HCT rozważenie leczenia ponatynibem } 45 \mathrm{mg} / \mathrm{d} \text { (Iclusig, Ariad), po uzyskaniu rejestracji EMEA, lub } \\
\text { omacetaksyną (Synribo, Cephalon) zarejestrowaną do leczenia chorych z mutacją T315I opornych na imatynib. } \\
\text { Jeżeli przyczyną niepowodzenia jest wykryta mutacja ABL, w wyborze leku należy wziąć pod uwagę jej wrażliwość. Potwierdzoną } \\
\text { w badaniach klinicznych oporność na dazatynib wykazują mutacje T315I/A, F317L i V299L, na nilotynib oporne są mutacje T315I, Y253H/F, } \\
\text { E255 V/K oraz F359 V. }\end{array}$} \\
\hline
\end{tabular}

potwierdzeniu oporności hematologicznej lub cytogenetycznej należy wykonać badania sprawdzające fazę choroby: rozmaz krwi obwodowej, aspirat szpiku wraz z badaniem cytogenetycznym w kierunku dodatkowych aberracji chromosomowych oraz analizę mutacji domeny kinazy genu ABL (Tab. IV). W przypadkach tych rekomendowane jest zastosowanie TKI II generacji, a u chorych, którzy ulegli progresji do fazy akceleracji lub kryzy blastycznej lub/i u pacjentów z obecną mutacją T315I, rozważenie przeprowadzenia alogenicznej transplantacji komórek hemopoetycznych (allo-HCT). U chorych z mutacją T315I niekwalifikujących się do allo-HCT należy uwzględnić zastosowanie ponatynibu w dawce $45 \mathrm{mg} / \mathrm{d}$ [65] (po zarejestrowaniu przez EMA) lub omacetaksyny (Synribo, Cephalon) zarejestrowanej przez EMA do leczenia chorych z mutacją T315I opornych na IM. Zalecaną dawką omacetaksyny $\mathrm{w}$ leczeniu indukcyjnym jest $1,25 \mathrm{mg} / \mathrm{m}^{2}$ s.c. dwa razy dziennie przez kolejnych $14 \mathrm{dni}$. Stosowanie leku należy powtarzać cyklicznie co 28 dni do uzyskania odpowiedzi. W leczeniu podtrzymującym lek należy stosować w dawce $1,25 \mathrm{mg} / \mathrm{m}^{2}$ s.c. dwa razy dziennie przez kolejnych 7 dni, a cykle powtarzać co 28 dni. Pacjenci pozostający w fazie przewlekłej, niekwalifikujący się do allo-HCT w drugiej linii leczenia, powinni otrzymać TKI II generacji - dazatynib w dawce $100 \mathrm{mg} / \mathrm{d}$ lub nilotynib w dawce $2 \times 400 \mathrm{mg} / \mathrm{d}$ (ewentualnie bozutynib w dawce $500 \mathrm{mg} / \mathrm{d}$ ) (Tab. VII). Wybór leku należy do lekarza prowadzącego. Po leczeniu 2. linii prowadzonym za pomocą TKI II generacji około 50\% pacjentów uzyskuje długotrwałą CCyR [66]. U pacjentów z wtórną opornością cytogenetyczną na IM podawany w dawce $400 \mathrm{mg} / \mathrm{d}$, z dobrą tolerancją leczenia oraz z licznymi schorzeniami współwystępującymi, z wysokim ryzykiem wystąpienia toksyczności hematologicznej i niehematologicznej $\mathrm{w}$ trakcie stosowania TKI II generacji można dokonać próby zwiększenia dawki leku na 600-800 mg/d [67, 68]. Eskalacji dawki IM nie zaleca się u pacjentów z pierwotną opornością hematologiczną lub cytogenetyczną [67]. Pacjenci z opornością lub nietolerancją leczenia pierwszej linii kwalifikujący się do allo-HCT pozostający w fazie przewlekłej także powinni otrzymać TKI II generacji: dazatynib $100 \mathrm{mg} / \mathrm{d}$ lub nilotynib 2 x $400 \mathrm{mg} / \mathrm{d}$ (lub ewentualnie bozutynib w dawce $500 \mathrm{mg} / \mathrm{d}$ ). Wybrane leczenie należy kontynuować, jeśli po 3 miesiącach leczenia uzyska się minimalną odpowiedź cytogenetyczną (minCyR; minimal Cytogenetic Response; Ph+ 6695\%), po 6 miesiącach CCyR, a po 12 miesiącach MMR [69]. Przy stwierdzeniu niepowodzenia terapii (bez określonej odpowiedzi w wymienionych punktach czasowych) zalecane jest rozważenie decyzji o przeprowadzeniu allo-HCT.

\section{Strategia wyboru TKI II generacji}

Ponieważ dotychczas nie przeprowadzono randomizowanych badań bezpośrednio porównujących TKI II generacji w przypadku nietolerancji/oporności na IM, wybór leku drugiego rzutu powinien nastąpić po indywidualnej, wnikliwej analizie ich przyczyn, po ocenie skuteczności, profilu działań ubocznych i bezpieczeństwa potencjalnego leku drugiego rzutu oraz analizie schorzeń współistniejących u konkretnego pacjenta i możliwości jego dostosowania się do zaleceń lekarskich dotyczących przyjmowania danego preparatu. W przypadku potwierdzenia obecności mutacji domeny kinazowej genu ABL: T315I, Y253H/F, E255 V/K oraz F359 V, preferowany jest dazatynib. W przypadku wystąpienia mutacji domeny kinazowej genu ABL: T315I/A, F317L i V299L, preferowany jest nilotynib. Zastosowanie ponatynibu należy rozważyć u chorych mutacją T315I niebędących kandydatami do allo-HCT [65]. W przypadku niewykrycia mutacji domeny kinazowej genu ABL wyboru leku 2. linii należy dokonać w oparciu o analizę profilu działań niepożądanych określonego TKI II generacji i profilu schorzeń współistniejących u danego pacjenta. Należy jednak podkreślić, że dotychczasowe rekomendacje ELN nie zawierają wskazań co do konieczności dokonywania wyboru TKI II generacji w zależności od obecności chorób towarzyszących. Sugeruje się, aby przy wyborze TKI II generacji wziąć pod 
uwagę zwłaszcza działania niepożądane pojawiające się najczęściej oraz te, które niosą ze sobą istotne zagrożenie życia. Dazatynib nie jest zalecany $u$ chorych $z$ rozpoznanym wcześniej wysiękiem opłucnowym lub osierdziowym oraz u pacjentów ze współistniejącym nadciśnieniem płucnym lub zastoinową niewydolnością serca [70, 71]. Nilotynib nie jest zalecany u osób z wcześniej zdiagnozowanym ostrym zapaleniem trzustki, niekontrolowaną cukrzycą, aktywną chorobą wątroby oraz ze współistniejącą miażdżycą tętnic obwodowych. Ostrożność w stosowaniu tego leku należy wykazać także w przypadku obecności u chorego czynników ryzyka choroby niedokrwiennej serca [72]. U pacjentów leczonych nilotynibem może dochodzić do hiperglikemii. Uważa się jednak, że w przypadkach tych zwykle nie dochodzi do rozwoju pełnoobjawowej cukrzycy. Okazało się także, że hiperglikemia może ustąpić po korekcie BMI i zastosowaniu odpowiedniej diety [73]. W badaniach przedklinicznych wykazano, że stosowanie nilotynibu prowadzi do wydłużenia odstępu QT [74]. Spostrzeżenie to nie znalazło potwierdzenia u chorych leczonych w ramach badania klinicznego ENESTnd [75, 76]. W zaleceniach NCCN zastrzeżono jednak, że wartość odstępu QT (skorygowanego do częstości akcji serca; QTc) przed leczeniem przekraczająca 450 msec stanowi przeciwwskazanie do stosowania nilotynibu. Podobnie wydłużenie QTc powyżej $480 \mathrm{msec}$ w trakcie stosowania leku jest podstawą do podjęcia decyzji o odstawieniu nilotynibu ze względu na ryzyko wystąpienia niebezpiecznych dla życia arytmii w tym torsade de pointe [77]. Ponieważ w badaniu DASISION stwierdzono wydłużenie QTc powyżej $450 \mathrm{msec}$ u 2,5\% pacjentów stosujących dazatynib oraz u 4,5\% pacjentów otrzymujących IM [78], powyższa rekomendacja dotyczy także tych leków. U chorych z wydłużonym QTc zalecane jest stosowanie bozutynibu, który nie wydłuża przewodnictwa w mięśniu serca [77].

\section{Leczenie pacjentów opornych na 2 lub więcej TKI}

Skuteczność leczenia 3. linii w sekwencji imatynib-dazatynib-nilotynib w porównaniu z sekwencją imatynib-nilotynib-dazatynib jest zbliżona [78] - MMR uzyskano u 15\%, PCyR u ok. 14\% i CCyR u 17\% pacjentów. Prawdopodobieństwo 30-miesięcznego OS wyniosło odpowiednio $98 \%$ u chorych w fazie przewlekłej i 76\% u pacjentów w AC. Wśród 15\% pacjentów, którzy zmarli w okresie obserwacji, zdecydowanie dominującym powodem progresji choroby była obecność mutacji T315I [78]. Leczenie 3. linii ponatynibem $w$ ramach badania PACE stosowano $u$ chorych nietolerujących lub opornych na IM, nilotynib lub dazatynib (53\% chorych otrzymało w uprzednim leczeniu przynajmniej 2 inhibitory). Po 12 miesiącach obserwacji CCyR uzyskano u 46\%, a MMR u 32\% chorych. Odsetek CCyR i MMR był wprawdzie większy u chorych z obecną mutacją T315I, ale wynik wstępnej analizy statystycznej sugeruje, że występowanie tej mutacji nie jest czynnikiem prognozującym lepszą odpowiedź, gdyż pacjenci z wykrytą mutacją byli młodsi, krócej chorowali na PBSz i otrzymali mniej linii leczenia [79]. W chwili analizy w leczeniu wciąż pozostawało $66 \%$ chorych w fazie przewlekłej PBSz. Najczęstszą przyczyną zaprzestania podawania ponatynibu była progresja choroby (18\%). Wyniki powyższych badań wskazują, że jeżeli pacjent pozostaje w fazie przewlekłej choroby, kolejnym krokiem po niepowodzeniu terapii 2. linii może być podanie TKI innego niż wcześniej stosowany, włącznie z próbą leczenia ponatynibem (po rejestracji EMA). Dotyczy to zwłaszcza u osób niekwalifikujących się do procedury allo-HCT.

\section{Czynniki wpływające na skuteczność leczenia TKI}

\section{Przestrzeganie zaleceń}

Przestrzeganie zaleceń lekarskich podczas stosowania TKI $\mathrm{w}$ terapii pacjentów $\mathrm{z}$ PBSz ma kluczowe znaczenie dla osiągnięcia i utrzymania optymalnej odpowiedzi na leczenie. Światowa Organizacja Zdrowia (WHO) definiuje stosowanie się pacjenta do zaleceń lekarskich jako „,stopień, w jakim zachowanie osoby przyjmującej lek, przestrzegającej diety i/lub dokonującej zmiany stylu życia - odpowiada ustalonym zaleceniom lekarza" [80]. Brak przestrzegania zaleceń dotyczących stosowania TKI stanowi niebagatelny problem w ocenie skuteczności leczenia i należy brać go zawsze pod uwagę u chorych wykazujących oporność. W badaniu ADAGIO (Adherence Assessment with Glivec: Indicators and Outcomes) wykazano, że około $30 \%$ pacjentów nie przestrzega zaleceń, a jedynie $14,2 \%$ chorych przyjmuje wszystkie dawki leku. Stwierdzono, że w grupie chorych z suboptymalną odpowiedzią na terapię znajduje się większy odsetek pacjentów nieprzestrzegających zaleceń $(28,2 \%)$ niż wśród chorych, którzy optymalnie odpowiedzieli na leczenie (7,3\%) [81]. Badanie Marina i wsp. dotyczyło pacjentów z PBSz, długotrwale leczonych imatynibem (mediana 59,7 miesiąca), będących w CCyR [82]. Wykazano w nim, że stopień przestrzegania zaleceń wynosił 98\% (zakres 22-104\%) i że istnieje silna zależność między stopniem przestrzegania zaleceń ( $\leq 90 \%$ us $>90 \%)$ a prawdopodobieństwem osiągnięcia MMR $(28,4 \%$ us $94,5 \%$; $<<0,001)$ i CMR (0\% us 43,8\%; P=0,002). Analiza wielowariantowa pozwoliła na zidentyfikowanie stopnia przestrzegania zaleceń (RR: 11,7; $\mathrm{P}=0,001$ ) i ekspresję hOCT-1 (human organic cation transporter-1) (RR: 1,79; $\mathrm{P}=0,038$ ) jako jedynych niezależnych czynników prognostycznych dla osiągnięcia MMR. Wykazano ponadto, że stopień przestrzegania zaleceń i nieuzyskanie MMR są niezależnymi czynnikami prognostycznymi dla utraty CCyR i przerwania terapii IM [83]. Przy leczeniu chorych z PBSz za pomocą TKI należy oceniać stopień przestrzegania zaleceń podczas każdej wizyty lekarskiej. U pacjentów, którzy nie osiągają dobrej odpowiedzi na leczenie, a także u tych, którzy tracą uzyskaną odpowiedź, stopień przestrzegania zaleceń wymaga szczególnie wnikliwej oceny. Należy pamiętać, że przestrzeganie zaleceń w dużym stopniu zależy od relacji lekarz-pacjent. Uwzględnienie oczekiwań pacjentów, poświęcony im czas, przekazywanie $\mathrm{w}$ prosty sposób informacji, podkreślanie znaczenia regularnego zażywania leków ma bardzo istotne znaczenie. Również identyfikacja objawów niepożądanych i ich skuteczne zwalczanie wpływa na poprawę przestrzegania dawkowania leku. Niezwykle ważne są także różne formy edukacji pacjenta i jego bliskich. 


\section{Mechanizmy oporności na leczenie}

Inhibitory kinaz tyrozynowych podlegają różnemu wchłanianiu w przewodzie pokarmowym, metabolizmowi w wątrobie (interakcje $\mathrm{z}$ innymi lekami lub substancjami), różnemu wiązaniu przez białka osocza, różnej aktywności mechanizmów transportu leku do i na zewnątrz komórki, a także enzymatycznej inaktywacji [84]. Rekomendowane jest, aby $\mathrm{u}$ chorych leczonych TKI systematycznie analizować listę pozostałych leków przyjmowanych przez pacjenta pod kątem ich możliwych interakcji z TKI poprzez wpływ indukujący lub hamujący podjednostkę CYP3A4 cytochromu p450 w wątrobie (lista induktorów i inhibitorów tego enzymu znajduje się na stronie FDA: http://www.fda.gov/drugs/developmentapprovalprocess/developmentresources/druginteractionslabeling/ ucm093664.htm). Do molekularnych przyczyn oporności należą: ewolucja klonalna, wystąpienie mutacji punktowych domeny kinazy genu ABL i zwiększona ekspresja kinaz z grupy zależnych od rodziny SRC (SFK; SRC Family of tyrosine Kinases) [85]. Wystąpienie mutacji domeny kinazy ABL jest dość częstą przyczyną oporności wtórnej, zwłaszcza u pacjentów w bardziej zaawansowanych fazach choroby [86], rzadko natomiast wykrywane są one w chwili rozpoznania choroby lub we wczesnych stadiach PBSz. U chorych opornych na IM pozostających w fazie przewlekłej PBSz obecność mutacji jest przyczyną oporności na TKI w mniej niż 50\% przypadków [87, 88]. Pozostaje przedmiotem kontrowersji, czy pojawienie się mutacji zlokalizowanych w obrębie tzw. pętli P (L248V, G250E, Q252H, Y253F, E255K, E255V) ma niekorzystne znaczenie rokownicze, [89-91]. Przeciwnie, obecność mutacji T315I jest uznanym wskaźnikiem niepowodzenia terapii TKI I i II generacji [87, 89, 92]. Wyniki testów in vitro określających wrażliwość komórek obciążonych poszczególnymi mutacjami na TKI mają (z wyjątkiem mutacji T315I) ograniczoną przydatność w przewidywaniu odpowiedzi klinicznej na zastosowanie konkretnego TKI [93]. Wyniki tych badań informują jedynie, o ile słabszy jest wpływ danego inhibitora na komórki obarczone konkretną mutacją genu ABL w porównaniu z komórkami niezmutowanymi [94]. Potwierdzoną w badaniach klinicznych oporność na dazatynib wykazują następujące mutanty kinazy ABL: T315I/A, F317L i V299L [95, 96]. Obecność mutacji T315I, Y253H/F, E255V/K oraz F359V [95, 97] wiąże się natomiast z opornością na nilotynib. W przypadku wykrycia mutacji T315I u pacjentów niekwalifikujących się do allo-HCT rekomenduje się leczenie za pomocą ponatynibu lub omacetaksyny (patrz rozdział: „Leczenie pacjentów z opornością/nietolerancją 1. linii leczenia imatynibem w dawce $400 \mathrm{mg} / \mathrm{d}$ ').

\section{Leczenie fazy akceleracji i kryzy blastycznej PBSz}

\section{Leczenie akceleracji PBSz}

Rozpoznanie PBSz w fazie akceleracji lub kryzy blastycznej ustalane jest u około 5-10\% chorych. W trakcie terapii IM progresja do fazy kryzy blastycznej lub akceleracji obserwowana jest w ciągu pierwszych 3 lat u około 2,6-1,5\% pacjentów rocznie, a od 4. roku terapii u mniej niż $1 \%$ chorych [98]. Kryteria diagnostyczne zamieszczono w tabeli VIII.
W przypadkach świeżo rozpoznanej PBSz w fazie akceleracji zalecanym leczeniem pierwszego wyboru, po wykluczeniu obecności mutacji T315I, jest podawanie IM w dawce $600 \mathrm{mg} / \mathrm{d}$. Celem takiego leczenia jest osiągnięcie odpowiedzi hematologicznej i przywrócenie fazy przewlekłej choroby. Zastosowanie IM $600 \mathrm{mg} / \mathrm{d}$ w leczeniu fazy akceleracji pozwala na uzyskanie CHR u 37\% chorych, CCyR u 19\% chorych i 3-letniego PFS u 40\% chorych [99]. Możliwości osiągnięcia trwałej odpowiedzi cytogenetycznej są niewielkie. Dlatego też po uzyskaniu fazy przewlekłej PBSz należy dążyć do allo-HCT z wykorzystaniem dawcy rodzinnego lub w pełni zgodnego w HLA dawcy niespokrewnionego. W przypadku niemożności uzyskania fazy przewlekłej PBSz w ciągu 1-3 miesięcy terapii IM należy zastosować (po wykluczeniu obecności mutacji T315I) nilotynib w dawce 2 x $400 \mathrm{mg} / \mathrm{d}$ lub dazatynib w dawce $140 \mathrm{mg} / \mathrm{d}$. Zastosowanie w tej sytuacji nilotynibu pozwala na uzyskanie odpowiedzi hematologicznej u 47\% chorych oraz 12-miesięcznego całkowitego przeżycia u 79\% pacjentów [100]. Ponowna ocena przeprowadzona w tej samej grupie pacjentów po 24 miesiącach leczenia wykazała, że uzyskanie CHR jest możliwe u 55\%, a MCyR u 32\% chorych. Szacowane OS i PFS oceniono odpowiednio na 70\% i 33\% [100]. Faza akceleracji może wystąpić również u chorych, którzy początkowo wykazywali dobrą odpowiedź na leczenie 1. linii IM. W takiej sytuacji, po wykluczeniu obecności mutacji T315I, zalecane jest zastosowanie nilotynibu w dawce $2 \times 400 \mathrm{mg} / \mathrm{d}$ lub dazatynibu w dawce $140 \mathrm{mg} / \mathrm{d}$, a po uzyskaniu fazy przewlekłej kwalifikacja do allo-HCT lub kontynuacja terapii, gdy nie ma możliwości przeprowadzenia transplantacji (brak dawcy, starszy wiek, choroby współistniejące).

\section{Leczenie kryzy blastycznej PBSz}

W większości prac dotyczących kryzy blastycznej PBSz za kryterium rozpoznania tej fazy choroby przyjmuje się wartość $\geq 30 \%$ blastów we krwi lub szpiku (podobnie w kryteriach ELN i EBMTR) (Tab. IX) [46]. Natomiast, wg kryteriów WHO, do rozpoznania kryzy blastycznej wystarczy $\geq 20 \%$ blastów w szpiku lub krwi obwodowej. Wartość $\geq 30 \%$ komórek blastycznych wydaje się jednak lepiej oddawać charakter tej fazy choroby, ponieważ rokowanie pacjentów z odsetkiem blastów pomiędzy 20-29\% jest lepsze [101]. Rozpoznanie kryzy blastycznej jest ustalane również w przypadku obecności pozaszpikowego nacieku z komórek blastycznych (chloroma). W przypadkach świeżo rozpoznanej $\mathrm{PBSz} \mathrm{w}$ fazie kryzy blastycznej leczeniem pierwszego wyboru jest IM podawany w dawce $800 \mathrm{mg} / \mathrm{d}$. Celem tej terapii jest uzyskanie odpowiedzi hematologicznej i przywrócenie przewlekłej fazy choroby. Terapia IM w dawce $800 \mathrm{mg} / \mathrm{d}$ pozwala na uzyskanie CHR u 25\% chorych i 3-letniego PFS u 10\% [102]. Wyniki leczenia tej fazy choroby IM w dawce $400-600 \mathrm{mg} / \mathrm{d}$ są złe. Średni czas przeżycia wynosi bowiem jedynie 6,9 miesiąca, a OS po 12 miesiącach tylko 32\%. W każdym przypadku osiągnięcia odpowiedzi cytogenetycznej, co zdarza się bardzo rzadko, należy dążyć do wykonania allo-HCT, która jako jedyna forma terapii stwarza jakąkolwiek szansę na trwałe wyleczenie. W przypadku kryzy blastycznej opornej na IM (tzn. nieuzyskania fazy przewlekłej po 1-3 miesięcy terapii) lub która wystąpiła w trakcie terapii IM, należy zastosować 
Tabela VIII - Kryteria fazy akceleracji PBSz wg ELN [46]

(zmodyfikowane)

Table VIII - ELN definition of accelerated phase of CML [46] (modified)

-15-29\% blastów we krwi lub szpiku kostnym

- blastów i promielocytów we krwi lub szpiku łącznie ponad 30\%, lecz mniej niż 30\% samych blastów

- odsetek bazofilów we krwi obwodowej lub szpiku $\geq 20 \%$

- długotrwała małopłytkowość poniżej $100 \mathrm{G} / 1$

niezwiązana z terapią

- pojawienie się ewolucji klonalnej w komórkach Ph dodatnich

Do rozpoznania fazy akceleracji wystarczy spełnienie jednego ww kryterium

dazatynib w dawce $140 \mathrm{mg} / \mathrm{d}$ [103]. Skuteczność tej formy terapii potwierdziły badania START. W badaniu START-B oceniono skuteczność dazatynibu w dawce $140 \mathrm{mg} / \mathrm{d} \mathrm{u}$ pacjentów z przełomem mieloblastycznym, w badaniu START-L u osób z przełomem limfoblastycznym choroby. Badania te wykazały, że zarówno u chorych z przełomem mieloblastycznym, jak i limfoblastycznym możliwe jest uzyskanie po 12 miesiącach terapii CCyR (odpowiednio u 33\% i 52\% pacjentów). W obu grupach badanych PFS było jednak krótkie (odpowiednio 6,7 i 3 miesiące). Po 24 miesiącach badania odsetek większych odpowiedzi hematologicznych u chorych otrzymujących dawkę $1 \times 140 \mathrm{mg} / \mathrm{d}$ oceniono na $28 \%$ u pacjentów z przełomem mieloblastycznymi i $42 \%$ u chorych z przełomem limfoblastycznym. Podobnie niesatysfakcjonujący był odsetek uzyskanych MCyR (odpowiednio 28\% i 50\%). Po 24 miesiącach przeżycie całkowite chorych z przełomem mieloblastycznym wyniosło $24 \%$, a wśród chorych z przełomem limfoblastycznym $21 \%$. Skuteczność dawkowania dazatynibu $2 \times 70 \mathrm{mg} / \mathrm{d}$ i $1 \times 140 \mathrm{mg} / \mathrm{d}$ jest podobna, jednak tolerancja leczenia jednorazową dawką $140 \mathrm{mg} / \mathrm{d}$ wydaje się być lepsza [104]. W przypadku nieskuteczności dazatynibu należy zastosować polichemioterapię przewidzianą dla ostrych białaczek mieloblastycznych (AML) lub limfoblastycznych (ALL). W przypadku kryzy mieloblastycznej zalecane są protokoły przewidziane dla AML [105] - najczęściej schemat DA (daunorubicyna $\mathrm{z}$ arabionzydem cytozyny), a w przypadku kryzy limfoblastycznej chemioterapia oparta na winkrystynie, adriamycynie i prednizonie [106]. Zastosowanie polichemioterapii w przypadku kryzy blastycznej może doprowadzić do nieodwracalnej pancytopenii (w sytuacji zniszczenia wszystkich komórek blastycznych, przy braku zdrowego klonu komórek macierzystych), dlatego ważne jest, aby przed rozpoczęciem polichemioterapii u osób będących kandydatami do allo-HCT proces doboru dawcy został rozpoczęty. Celem powyżej opisanych sposobów leczenia jest przede wszystkim przywrócenie fazy przewlekłej choroby. W każdym przypadku, gdy jest to możliwe, należy dążyć do przeprowadzenia allo- HCT [101].

W przypadku wykrycia mutacji T315I u chorych z PBSz w fazie akceleracji lub kryzy blastycznej należy zastosować polichemioterapię wg zasad przedstawionych powyżej. Możliwe jest także zastosowanie ponatynibu. Jego podawanie umożliwia uzyskanie odpowiedzi hematologicznej i CCyR odpowiednio u $50 \%$ i u $24 \%$ chorych w fazie akceleracji i u $37 \% \%$ oraz u $29 \%$ chorych w fazie kryzy blastycznej [107].
Tabela IX - Kryteria fazy kryzy blastycznej PBSz wg ELN

[46]

Table IX - ELN definitin of blast phase of CML [46]

- blasty stanowią $\geq 30 \%$ leukocytów krwi obwodowej lub

komórek jądrzastych szpiku

- pozaszpikowa proliferacja blastów

\section{Wskazania do alogenicznej transplantacji komórek hemopoetycznych w PBSz}

Do czasu zastosowania imatynibu allo-HSC była uważana za jedyną metodę pozwalającą na trwałe wyleczenie PBSz. Jednak ze względu na duże ryzyko powikłań związanych $\mathrm{z}$ tą procedurą - w tym śmiertelnych, od czasu wprowadzenia TKI allo-HCT jest metodą zarezerwowaną do zastosowania w przypadku uzyskania drugiej fazy przewlekłej po wystąpieniu akceleracji lub kryzy blastycznej, a także w obliczu całkowitej oporności na TKI. 10-letnie całkowite przeżycie chorych na PBSz poddanych allo-HCT wynosi $60 \%$, a EFS - 50\% [108]. Transplantacje wykonane w drugiej i kolejnej fazie przewlekłej mają gorsze rokowanie. 18-letnie całkowite przeżycie chorych poddanych przeszczepieniu w pierwszej fazie przewlekłej wynosi 50\%, a 20\% u chorych poddanych transplantacji w drugiej i kolejnych fazach przewlekłych [109]. Przeżycie po allo-HCT zależy głównie od wieku pacjenta, fazy choroby $\mathrm{w}$ momencie przeszczepienia i stopnia zgodności w układzie HLA [107]. Wznowy choroby po allo-HCT są obserwowane z częstością około 1\% rocznie nawet do 21 lat po transplantacji [110]. Do allo-HCT z zastosowaniem mieloalacyjnego kondycjonowania od dawcy rodzinnego i niespokrewnionego kwalifikują się chorzy poniżej 55.-60. roku życia. U osób starszych (60-65 lat) kwalifikowanych do allo-HCT można zastosować zredukowane kondycjonowanie. Allo-HCT należy wykonywać w fazie przewlekłej ze względu na mniejsze ryzyko powikłań związanych z transplantacją i mniejszy odsetek nawrotów [110]. Wcześniejsza terapia IM, dazatynibem lub nilotynibem przed allo-HCT nie ma negatywnego wpływu na skuteczność, wyniki i powikłania związane z transplantacją. Wskazania do alogenicznej transplantacji od dawcy rodzinnego lub niespokrewnionego przedstawiono $\mathrm{w}$ tabeli $\mathrm{X}$.

\section{Leczenie PBSz u kobiet w ciąży}

\section{Rozpoznanie PBSz w ciąży}

PBSz stanowi około 10\% wszystkich białaczek rozpoznawanych w ciąży. Częstość jest szacowana na około 1:100 000 ciąż na rok. Leczeniem $\mathrm{z}$ wyboru w I trymestrze ciąży są leukaferezy, a w II i III trymestrze interferon alfa (INF $\alpha$ ). W przypadku nadpłytkowości z liczbą PLT > $500 \times 10^{9} / \mathrm{L}$ wskazane jest dodatkowo stosowanie aspiryny lub heparyny drobnocząsteczkowej [111, 112].

\section{Nieplanowana ciąża podczas terapii IM}

W przypadku ciąży, do której doszło u pacjentki leczonej IM, konieczna jest ocena ryzyka związanego z kontynuowaniem 
Tabela X - Wskazania do alogenicznej transplantacji komórek hemopoetycznych (allo-HCT)

Table X - Recommendations for AlloHSCT

\begin{tabular}{lc}
\hline Czas & grupa pacjentów \\
\hline Diagnoza & Poszukiwanie dawcy RODZINNEGO \\
& $\begin{array}{l}\text { w fazie AP, BC } \\
\text { wiek poniżej 20. rż } \\
\text { obecne warunki } \\
\text { ostrzeżenia (ryzyko CCA) } \\
\text { wszyscy pacjenci }\end{array}$ \\
Niepowodzenie IM lub 2GTKI & Poszukiwanie dawcy NESPOKREWNIONEGO \\
wiagnoza & w fazie AP, BC \\
Niepowodzenie IM & $\begin{array}{l}\text { progresja do AP, BC } \\
\text { T315I } \\
\text { oporność hematologiczna na IM } \\
\text { niepowodzenie }\end{array}$ \\
W trakcie lub po leczeniu 2GTKI & Przeprowadzenie allogenicznego przeszczepienia \\
Diagnoza & w fazie AP, BC (zalecane leczenie wstępne 2GTKI) \\
progresja do AP, BC (zalecane leczenie wstępne 2GTKI) & T315I \\
\hline
\end{tabular}

terapii dla płodu i przerwaniem leczenia dla matki. Badania przeprowadzane na zwierzętach wykazały teratogenne działanie IM. Również doświadczenia zebrane na podstawie obserwacji przebiegu ciąż u kobiet leczonych IM wskazują na prawdopodobieństwo zwiększenia częstości wad wrodzonych u płodu [111, 113]. Największe ryzyko teratogennego działania TKI istnieje w pierwszym trymestrze ciąży i przynajmniej wówczas terapia powinna być przerwana. Ryzyko związane $\mathrm{z}$ przerwaniem terapii u matki zależy przede wszystkim od aktualnej odpowiedzi na IM. Im dłuższa i głębsza jest odpowiedź molekularna u pacjentki, tym mniejsze jest ryzyko jej utraty po odstawieniu terapii TKI. W przypadku utrzymywania się $\mathrm{MMR} / \mathrm{MR}^{4,5}$ chora zwykle nie wymaga terapii przez cały okres ciąży. U pacjentek $\mathrm{z}$ utratą MMR lub CCyR wskazana jest terapia INF $\alpha$. U pacjentek pozostających $\mathrm{w}$ MMR/MR ${ }^{4,5}$ podczas ciąży dopuszczalne jest przedłużenie okresu odstawienia leku i karmienie dziecka piersią. U wszystkich pozostałych pacjentek konieczny jest jak najszybszy powrót do terapii IM [111, 113].

\section{Planowanie ciąży u chorej na PBSz leczonej IM}

Planowanie ciąży u chorej na PBSz leczonej IM wymaga przede wszystkim dokładnego omówienia ryzyka dla niej i dla dziecka w zależności od wybranego postępowania. Optymalnie, planując ciążę, chora powinna być w długotrwałej (co najmniej 2 lata) $\mathrm{MR}^{4,5}$. Ze względu na potencjalne teratogenne działanie IM należy go odstawić około 7 dni przed rozpoczęciem starań o dziecko (okres eliminacji leku). Okres od odstawienia leku do zajścia w ciążę nie powinien przekraczać 6 miesięcy (zalecana jest ewentualna stymulacja hormonalna) [111, 114].

\section{TKI II generacji a ciąża}

Dane literaturowe dotyczące ciąży u pacjentek przyjmujących TKI II generacji są bardzo skąpe. Podobnie jak w przypadku IM, leki te mają potencjalne działanie teratogenne, a zatem strategia postępowania powinna być analogiczna jak w przypadku IM.

\section{Ojcostwo a stosowanie TKI}

Stwierdzono, że dzieci mężczyzn leczonych IM w trakcie prokreacji rozwijają się prawidłowo. Dlatego też u mężczyzn nie zaleca się przerwania terapii IM w okresie starań o ciążę $[111,115]$. Brak danych dotyczących tego zagadnienia w odniesieniu do TKI II generacji.

\section{Wkład autorów/Authors' contributions}

Według kolejności.

\section{Konflikt interesu/Conflict of interest}

Wszyscy autorzy pobierali honoraria za konsultacje od firm Novartis i BMS.

\section{Finansowanie/Financial support}

Nie występuje.

\section{Etyka/Ethics}

Treści przedstawione $\mathrm{w}$ artykule są zgodne $\mathrm{z}$ zasadami Deklaracji Helsińskiej, dyrektywami EU oraz ujednoliconymi wymaganiami dla czasopism biomedycznych.

\section{P IŚ M IEN N ICT W O/REFERENCES}

[1] Jemal A, Siegel R, Xu J, et al. Cancer statistics, 2010. CA Cancer J Clin 2010;60:277-300.

[2] Gleevec (imatinib) [prescribing information]. East Hanover, NJ: Novartis Pharmaceuticals Corporation; 2012, January.

[3] Druker BJ, Guilhot F, O'Brien SG, et al. Five-year follow-up of patients receiving imatinib for chronic myeloid leukemia. N Engl J Med 2006;35:2408-2417. 
[4] de Lavallade H, Apperley JF, Khorashad JS, et al. Imatinib for newly diagnosed patients with chronic myeloid leukemia: incidence of sustained responses in an intention-to-treat analysis. J Clin Oncol 2008;26:3358-3363.

[5] Deininger M, O'Brien SG, Guilhot F, et al. International Randomized Study of Interferon Vs STI571 (IRIS) 8-year follow up: sustained survival and low risk for progression or events in patients with newly diagnosed chronic myeloid leukemia in chronic phase (CML-CP) treated with imatinib. Blood 2009;114:462.

[6] Kantarjian HM, Giles FJ, Bhalla KN, et al. Nilotinib is effective in patients with chronic myeloid leukemia in chronic phase after imatinib resistance or intolerance: 24-month follow-up results. Blood 2011;117:1141-1145.

[7] Hochhaus A, Baccarani M, Deininger M, et al. Dasatinib induces durable cytogenetic responses in patients with chronic myelogenous leukemia in chronic phase with resistance or intolerance to imatinib. Leukemia 2008;22:1200-1206.

[8] Khoury HJ, Cortes JE, Kantarjian HM, et al. Bosutinib is active in chronic phase chronic myeloid leukemia after imatinib and dasatinib and/or nilotinib therapy failure. Blood 2012;119:3403-3412.

[9] Zhou T, Commodore L, Huang WS, et al. Structural mechanism of the pan-BCR/ABL inhibitor ponatinib (AP24534): lessons for overcoming kinase inhibitor resistance. ChemBiol Drug Des 2011;77:1-11.

[10] Kim D-W, Cortes JE, Pinilla-Ibarz J, et al. Efficacy and Safety of Ponatinib According to Prior Approved Tyrosine Kinase Inhibitor (TKI) Therapy in Patients with Chronic Myeloid Leukemia in Chronic Phase (CP-CML): Results From the PACE Trial. Blood (ASH Annual Meeting Abstracts) 2012;120. Abstract 3749.

[11] O'Brien S, Abboud CN, Akhtari M, et al. NCCN Clinical Practice Guidelines in Oncology for Chronic Myelogenous Leukemia. J Natl Compr Canc Netw 2012;10:64-110.

[12] Baccarani M, Pileri S, Steegmann JL, et al., ESMO Guidelines Working Group. Chronic myeloid leukemia: ESMO Clinical Practice Guidelines for diagnosis, treatment and followup. AnnOncol 2012 Oct;23 Suppl 7:vii72-vii77.

[13] Mahon FX, Réa D, Guilhot J, et al. Discontinuation of imatinib in patients with chronic myeloid leukaemia who have maintained complete molecular remission for at least 2 years: the prospective, multicentre Stop Imatinib (STIM) trial. Lancet Oncol 2010;11:1029-1035.

[14] Sokal JE, Cox EB, Baccarani M, et al. Prognostic discrimination in 'good-risk'chronic granulocytic leukemia. Blood 1984;63:789-799.

[15] Hasford J, Pfirrmann M, Hehlmann R, et al. A new prognostic score for survival ofpatients with chronic myeloid leukemia treated with interferon alfa. J NatlCancerInst 1998;90:850-858.

[16] Hasford J, Baccarani M, Hoffmann V, et al. Predicting complete cytogeneticresponse and subsequent progression-free survival in 2060 patients with CML onimatinib treatment: the EUTOS score. Blood 2011;118:686-692.

[17] O'Brien SG, Guilhot F, Larson RA, et al. Imatinib compared with interferon and low-dose cytarabine for newly diagnosed chronic-phase chronic myeloid leukemia. N Engl J Med 2003;348:994-1004.

[18] Deininger M, O'Brien SG, Guilhot F, et al. International Randomized Study of Interferon vs STI571 (IRIS) 8-year follow up: sustained survival and low risk for progression or events in patients with newly diagnosed chronic myeloid leukemia in chronic phase (CMLCP) treated with imatinib. ASH Annual Meeting Abstracts. Blood 2009;114:1126.
[19] Druker BJ, Guilhot F, O'Brien SG, et al. Five-year follow-up of patients receiving imatinib for chronic myeloid leukemia. N Engl J Med 2006;355:2408-2417.

[20] de Lavallade H, Apperley JF, Khorashad JS, et al. Imatinib for newly diagnosed patients with chronic myeloid leukemia: incidence of sustained responses in an intention-to-treat analysis. J Clin Oncol 2008;26:3358-3363.

[21] Lucas CM, Wang L, Austin GM, et al. A population study of imatinib in chronic myeloid leukaemia demonstrates lower efficacy than in clinical trials. Leukemia 2008;22:1963-1966.

[22] Tasigna (nilotinib) [prescribing information]. East Hanover, NJ: Novartis Pharmaceuticals Corporation; 2011, November.

[23] Sprycel (dasatinib) [prescribing information]. Princeton, NJ: Bristol- Myers Squibb Company; 2011, October.

[24] Kantarjian H, Baccarani M, Jabbour E, et al. Secondgeneration tyrosine kinase inhibitors: the future of frontline CML therapy. Clin Cancer Res 2011 Apr 1;17(7): 1674-1683.

[25] Rosti G, Castagnetti F, Gugliotta G, et al. Excellent outcomes at 3 years with nilotinib $800 \mathrm{mg}$ daily in early chronic phase, $\mathrm{Ph}+$ chronic myeloid leukemia (CML): results of a phase 2 GIMEMA CML WP Clinical Trial. ASH Annual Meeting Abstracts. Blood 2010;116:359.

[26] Cortes JE, Jones D, O'Brien S, Jabbour E, Konopleva M, Ferrajoli A, et al. Nilotinib as front-line treatment for patients with chronic myeloid leukemia in early chronic phase. J Clin Oncol 2010 20;28(3):392-397.

[27] Saglio G, Kim DW, Issaragrisil S, et al. Nilotinib versus imatinib for newly diagnosed chronic myeloid leukemia. N Engl J Med 2010;362:2251-2259.

[28] Hughes TP, Hochhaus A, Saglio G, et al. ENESTnd update: continued superiority of nilotinib versus imatinib in patients with newly diagnosed chronic myeloid leukemia in chronic phase (CML-CP). ASH Annual Meeting Abstracts. Blood 2010;116:207.

[29] Kantarjian HM, Hochhaus A, Saglio G, et al. Nilotinib versus imatinib for the treatment of patients with newly diagnosed chronic phase, Philadelphia chromosomepositive, chronic myeloid leukaemia: 24 - month minimum follow-up of the phase 3 randomised ENESTnd trial. Lancet Oncol 2011;12:841-851.

[30] Larson RA, Hochhaus A, Hughes TP, et al. Nilotinib vs imatinib in patients with newly diagnosed Philadelphia chromosome-positive chronic myeloid leukemia in chronic phase ENESTnd 3-year follow-up Leukemia 2012;26:21972203.

[31] Kantarjian H, Kim D-W, Issaragrisil S, et al. Enestnd 4-Year (y) Update: Continued Superiority of Nilotinib Vs Imatinib in Patients (pts) with Newly Diagnosed Philadelphia Chromosome-Positive (Ph+) Chronic Myeloid Leukemia in Chronic Phase (CML-CP). Blood 2012;120:1676.

[32] Cortes JE, Jones D, O'Brien S, et al. Results of dasatinib therapy in patients with early chronic-phase chronic myeloid leukemia. J Clin Oncol 2010;28:398-404.

[33] Radich JP, Kopecky KJ, Kamel-Reid S, et al. A randomized phase II trial of dasatinib $100 \mathrm{mg}$ vs imatinib $400 \mathrm{mg}$ in newly diagnosed chronic myeloid leukemia in chronic phase (CML-CP): the S0325 Intergroup Trial. ASH Annual Meeting Abstracts. Blood 2010;116:LBA-LBA6.

[34] Kantarjian H, Shah NP, Hochhaus A, et al. Dasatinib versus imatinib in newly diagnosed chronic-phase chronic myeloid leukemia. N Engl J Med 2010;362:2260-2270.

[35] Kantarjian HM, Shah NP, Cortes JE, et al. Dasatinib or imatinib in newly diagnosed chronic-phase chronic myeloid leukemia: 2-year follow-up from a randomized phase 3 trial (DASISION). Blood 2012;119: 1123-1129. 
[36] Hochhaus A, Saglio G, Chuah C, et al. Dasatinib and imatinibinduced reductions in BCR-ABL transcript levels below $10 \%$ at 3 months are associated with improved responses in patients with newly diagnosed chronic myeloid leukemia in chronic phase (CML-CP): Analysis of molecular response kinetics in the DASISION trial (Abstract). Blood 2011;118(21):2767.

[37] Cortes JE, Baccarani M, Guilhot F, et al. Phase III, Randomized, Open-Label Study of Daily Imatinib Mesylate 400 mg Versus 800 mg in Patients With Newly Diagnosed, Previously Untreated Chronic Myeloid Leukemia in Chronic Phase Using Molecular End Points: Tyrosine Kinase Inhibitor Optimization and Selectivity Study. J Clin Oncol 2009;28:424-430.

[38] Baccarani M, Druker BJ, Cortes-Franco J, et al. 24 months update of the TOPS study: a phase III, randomized, openlabel study of $400 \mathrm{mg} / \mathrm{d}$ (SD-IM) versus $800 \mathrm{mg} / \mathrm{d}$ (HD-IM) of imatinib mesylate (IM) in patients (pts) with newly diagnosed, previously untreated chronic myeloid leukemia in chronic phase (CML-CP). Blood 2009;114. abstract 337.

[39] Hochhaus A, Baccarani M, Deininger M, et al. Dasatinib induces durable cytogenetic responses in patients with chronic myelogenous leukemia in chronic phase with resistance or intolerance to imatinib. Leukemia 2008;22 (6):1200-1206.

[40] Hochhaus A, Kantarjian HM, Baccarani M, et al. Dasatinib induces notable hematologic and cytogenetic responses in chronic-phase chronic myeloid leukemia after failure of imatinib therapy. Blood 2007;109.(6):2303-2309.

[41] Kantarjian H, Pasquini R, Lévy V, et al. Dasatinib or highdose imatinib for chronic-phase chronic myeloid leukemia resistant to imatinib at a dose of 400 to 600 milligrams daily: two-year follow-up of a randomized phase 2 study (START-R). Cancer 2009;115:4136-4147.

[42] Apperley JF, Cortes JE, Kim DW, et al. Dasatinib in the Treatment of Chronic Myeloid Leukemia in Accelerated Phase After Imatinib Failure: The START A Trial. JCO 2009;27:3472-3479.

[43] Shah NP, Kantarjian HM, Kim DW, et al. Intermittent target inhibition with dasatinib $100 \mathrm{mg}$ once daily preserves efficacy and improves tolerability in imatinibresistant and -intolerant chronic-phase chronic myeloid leukemia. J Clin Oncol 2008;26:3204-3212.

[44] Kantarjian H, Cortes J, Kim D-W, et al. Phase 3 study of dasatinib $140 \mathrm{mg}$ once daily versus $70 \mathrm{mg}$ twice daily in patients with chronic myeloid leukemia in accelerated phase resistant or intolerant to imatinib: 15-month median follow-up. Blood 2009;113:6322-6329.

[45] Kantarjian H, Giles F, Wunderle L, et al. Nilotinib in imatinib-resistant CML and Philadelphia chromosomepositive ALL. N Engl J Med 2006;354:2542-2551.

[46] Giles FJ, le Coutre PD, Pinilla-Ibarz J, et al. Nilotinib in imatinib-resistant or imatinib-intolerant patients with chronic myeloid leukemia in chronic phase: 48-month follow-up results of a phase II study. Leukemia 2013;27: 107-112.

[47] Baccarani M, Cortez J, Pane F, et al. Chronic Myeloid Leukemia: An Update of Concepts and Management Recommendations of European LeukemiaNet. Journal of Clinical Oncology 2009;27:6041.

[48] Simonsson B, on behalf of the IRIS study group. Beneficial effects of cytogenetic and molecular response on long term outcome in patients with newly diagnosed chronic myeloid leukemia in chronic phase (CML-CP) treated with Imatinib (IM): update from the IRIS study [abstract]. Blood 2005;106(52a). Abstract no. 166.

[49] Schmidli H, Peng B, Riviere GJ, et al. Population pharmacokinetics of imatinib mesylate in patients with chronic-phase chronic myeloid leukaemia: results of a phase III study. Br J Clin Pharmacol 2005;60:35-44.

[50] Zonder JA, Pemberton P, Brandt H, et al. The effect of dose increase of imatinib mesylate in patients with chronic or accelerated phase chronic myelogenous leukemia with inadequate hematologic or cytogenetic response to initial treatment. Clin Cancer Res 2003;9:2092-2097.

[51] Hughes TP, Branford S. Molecular monitoring of BCR/ABL as a guide to clinical management in chronic myeloid leukaemia. Blood Rev 2006;20:29-32.

[52] Hughes TP, Branford S, White DL, et al. Impact of early dose intensity on cytogenetic and molecular responses in chronic-phase CML patients receiving $600 \mathrm{mg}$ /day of imatinib as initial therapy. Blood 2008;112:3965-3999.

[53] Sacha T, Foryciarz K, Zawada M, et al. Badanie ilości transkryptu bcr/abl po 3 miesiącach leczenia imatynibem przewlekłej białaczki szpikowej jako czynnik prognostyczny dla uzyskania większej odpowiedzi molekularnej i optymalnego wyniku leczenia wg rekomendacji ELN. Przegl Lek 2011;68(2):83-86.

[54] Marin D, Hedgley C, Clark RE, et al. Predictive value of early molecular response in patients with chronic myeloid leukemia treated with first-line dasatinib. J Clin Oncol 2012;30(3):232-238.

[55] Hehlmann R, Jung-Munkwitz S, Lauseker M, et al. Superior CMR-rates with tolerability-adapted imatinib $800 \mathrm{mg}$ vs $400 \mathrm{mg}$ vs $400 \mathrm{mg}$ + IFN in CML: the randomized German CML-study IV. W: Presented at: 52nd Annual Meeting of American Society of Hematology; 4-7 December 2010.

[56] Marin D, Hedgley C, Clark RE, et al. Brief report Predictive value of early molecular response in patients with chronic myeloid leukemia treated with first-line dasatinib. Blood 2012;120:291-294.

[57] Hanfstein B, Mueller MC, Hehlmann R, et al. Early molecular and cytogenetic response is predictive for longterm progression-free and overall survival in chronic myeloid leukemia (CML). Leukemia 2012;26:2096-2102.

[58] Hochhaus A, Boque C, Garelik MB, et al. Molecular response kinetics and BCR/ABL reductions in Patients with newly diagnosed chronic myeloid leukemia in Chronic phase (cml-cp) receiving dasatinib vs imatinib: DASISION 3-year follow-up. Haematologica 2012;97(s1). abstract 0192.

[59] Saglio B. Early Response (Molecular and Cytogenetic) and Long-term Outcomes in Newly Diagnosed Chronic Myeloid Leukemia in Chronic Phase (CML-CP): Exploratory Analysis of DASISION 3-Year Data. Blood 2012;120 (21):1675.

[60] Franceschino A, Tornaghi L, Piazza R, et al. Imatinib failed to eradicate chronic myeloid leukemia in a patient with minimal residual disease. Haematologica 2006;91(6 Suppl): ECR14.

[61] Castagnetti F, Gugliotta G, Palandri F, et al. Chronic Myeloid Leukemia (CML) Patients with "Suboptimal" Response to Imatinib (IM) According to European LeukemiaNet Criteria Have a Poorer Outcome with Respect to "Optimal" Responders: A GIMEMA CML WORKING PARTY Analysis. Blood 2009;112(11). Str. 2196.

[62] Alvarado Y, Kantarjian H, Faderl S, et al. Significance of Suboptimal Response to Imatinib, as Defined by the European LeukemiaNet, in Long-Term Outcome for Patients (Pts) with Chronic Phase (CP) Chronic Myeloid Leukemia (CML). Blood 2007;110(11):1932.

[63] Marin D, Milojkovic D, Olavarria E, et al. European LeukemiaNet criteria for failure or suboptimal response reliably identify patients with CML in early chronic phase treated with imatinib whose eventual outcome is poor. Blood 2008;112:4437-4444.

[64] Sacha T. Ocena skuteczności leczenia chorych na przewlekłą białaczkę szpikową inhibitorami kinaz 
tyrozynowych przy pomocy metod biologii molekularnej. Kraków: Rozprawa habilitacyjna. Medycyna Praktyczna; 2012.

[65] Jabbour E, Deininger M, Hochhaus A. Management of adverse events associated with tyrosine kinase inhibitors in the treatment of chronic myeloid leukemia. Leukemia 2011;25:201-210.

[66] Cortes J, Kim D, Pinilla-Ibarz J, et al. Initial Findings From the PACE Trial: A Pivotal Phase 2 Study of Ponatinib in Patients with CML and Ph+ ALL Resistant or Intolerant to Dasatinib or Nilotinib, or with the T315I Mutation. Blood 2011;118(21):109.

[67] Milojkovic D, Apperley JF, Gerred G, et al. Responses to second line tyrosine kinase inhibitors are durable; an intention-to-treat analysis in chronic myeloid leukemia patients. Blood 2012;119:1838-1843.

[68] Kantarijan HM, Larson RA, Guilhot F, et al. Efficacy of imatinib dose escalation In patients with chronic myeloid leukemia In chronic phase. Cancer 2009;115:551-560.

[69] Milojkovic D, Nicholson E, Apperley JF, et al. Early prediction of success or failure of treatment with secondgeneration tyrosine kinase inhibitors in patients with chronic myeloid leukemia. Haematologica 2010;95: 224-231.

[70] Orlandi EM, Rocca B, Pazzano AS, et al. Reversible pulmonary arterial hypertension likely related to longterm, low-dose dasatinib treatment for chronic myeloid leukaemia. Leuk Res 2012;36(1):e4-e6.

[71] Quintas-Cardama A, Kantarjian H, O'Brien S, et al. Pleural effusion in patient with chronic myelogenes leukemia treated with dasatinib after imatinib failure. J Clin Oncol 2007;25:3908-3914.

[72] Aichberger KJ, Herndlhofer S, Schernthaner G-H, et al. Progressive peripheral arterial occlusive disease and other vascular events during nilotinib therapy in CML. Am J Hematol 2011;7:533-539.

[73] Valent P. Severe adverse events associated with the use of second-linie BCR/ABl tyrosine kinase inhibitors; preferential occurrens in patients with comorbiditis. Haematologica 2011;96:1395-1397.

[74] Wolf A, Couttet P, Dong M, et al. Preclinical evaluation of potential nilotinib cardiotoxicity. Leuk Res 2011;35(5): 631-637.

[75] Saglio G, Kim DW, Issaragrisil S, et al. Nilotinib versus imatinib for newly diagnosed chronic myeloid leukemia. N Engl J Med 2010;362(24):2251-2259.

[76] Kim TD, Coutre P, Schwarz M, et al. Clinical cardiac safety profile of nilotinib. Haematologica 2012;97(6):883-889.

[77] NCCN clinical practice guidelines in oncology. CML. Version 4.2013 www.nccn.org.

[78] Rossi AR, Breccia M, Abruzzese E, et al. Outcome of 82 chronic myeloid leukemia patients treated with nilotinib or dasatinib after failure of two prior tyrosine kinase inhibitors. Haematologica 2013;98(3):399-403.

[79] Cortes JE, Kim DW, Ibarz JP, et al. A Pivotal Phase 2 Trial of Ponatinib in Patients with Chronic Myeloid Leukemia (CML) and Philadelphia Chromosome-Positive Acute Lymphoblastic Leukemia (Ph+ALL) Resistant or Intolerant to Dasatinib or Nilotinib, or with the T315I BCR/ABL Mutation: 12-Month Follow-up of the PACE Trial 54. Annual Meeting 2013;163.

[80] WHO 2003; www.who.int/chp/knowledge/publications/ adherence_report/en. Accessed Dec. 2011.

[81] Noens L, van Lierde MA, De Bock R, et al. Prevalence, determinants, and outcomes of nonadherence to imatinib therapy in patients with chronic myeloid leukemia: the ADAGIO study. Blood 2009;113:5401-5411.

[82] Marin D, Bazeos A, Mahon FX, et al. Adherence is the critical factor for achieving molecular responses in patients with Chronic Myeloid Leukemia who achieve complete cytogenetic responses on Imatynib. J Clin Oncol 2010;28:2381-2388

[83] Ibrahim A, Eliasson L, Apperley J, et al. Poor adherence is the main reason for loss of CCyR and imatinib failure for CML patients on long term therapy. Blood 2011;117:3733-3736.

[84] Apperley J. Part I: mechanisms of resistance to imatinib in chronic myeloid leukaemia. Lancet Oncol 2007;8(11): 1018-1029.

[85] Wu J, Meng F, Kong LY, et al. Association between imatinib- resistant BCR/ABL mutation-negative leukemia and persistent activation of LYN kinase. J Natl Cancer Inst 2008;100:926-939.

[86] Soverini S, Martinelli G, Rosti G, et al. ABL mutations in late chronic phase chronic myeloid leukemia patients with upfront cytogenetic resistance to imatinib are associated with a greater likelihood of progression to blast crisis and shorter survival: a study by the GIMEMA Working Party on Chronic Myeloid Leukemia. J Clin Oncol 2005;23:4100-4109.

[87] Soverini S, Colarossi S, Gnani A, et al. Contribution of ABL kinase domain mutations to imatinib resistance in different subsets of Philadelphia-positive patients: By the GIMEMA Working Party on Chronic Myeloid Leukemia. Clin Cancer Res 2006;12:7374-7379.

[88] Ernst T, Erben P, Muller MC, et al. Dynamics of BCR/ABL mutated clones prior to hematologic or cytogenetic resistance to imatinib. Haematologica 2008;93:186-192.

[89] Khorashad JS, Anand M, Marin D, et al. The presence of a BCR/ABL mutant allele in CML does not always explain clinical resistance to imatinib. Leukemia 2006;20:658-663.

[90] Jabbour E, Kantarjian H, Jones D, et al. Frequency and clinical significance of BCR/ABL mutations in patients with chronic myeloid leukemia treated with imatinib mesylate. Leukemia 2006;20:1767-1773.

[91] Nicolini FE, Corm S, Le QH, et al. Mutation status and clinical outcome of 89 imatinib mesylate resistant chronic myelogenous leukemia patients: A retrospective analysis from the French Intergroup of CML. Leukemia 2006;20:1061-1066.

[92] Soverini S, Iacobucci I, Baccarani M, et al. Targeted therapy and the T315I mutation in Philadelphia-positive leukemias. Haematologica 2007;92:437-439.

[93] Laneuville P, DiLea C, Yin OQP, et al. Comparative in vitro cellular data alone are insufficient to predict clinical responses and guide the choice of BCR/ABL inhibitor for treating imatinib-resistant chronic myeloid leukemia. J Clin Oncol 2010;28:e169-e171.

[94] Gambacorti-Passerini C, Piazza R, Perini P, et al. Reply to P. Laneuville et al. J Clin Oncol 2010;28:e172.

[95] Deininger M, Mauro M, Matloub Y, et al. Prevalence of T315I, dasatinib-insensitive BCR/ABL mutations, and nilotinib-specific resistant mutations at the time of imatinib resistance in chronic myeloid leukemia (CP-CML). Blood 2008;112:11. Abs 3236.

[96] Jabbour E, Kantarjian HM, Jones D, et al. Characteristics and outcome of chronic myeloid leukemia patients with F317L BCR/ABL kinase domain mutation after therapy with tyrosine kinase inhibitors. Blood 2008;112:4839-4841.

[97] Deininger M. Nilotinib Clin Cancer Res 2008;14:4027-4031.

[98] Deininger M, O'Brien S, Guilhot F, et al. IRIS 8-year follow up: sustained survival and low risk for progression or events in patients with newly diagnosed chronic myeloid leukemia in chronic phase treated with imatinib. Blood 2009;114:1126.

[99] Silver RT, Talpaz M, Sawyers CL, et al. Four years of followup of 1072 patients with late chronic phase,accelerated phase or blast crisis chronic myeloid leukemia treated with imatinib in three large phase II trials. Blood 2004;104:11a. Abs 23. 
[100] le Coutre PD, Giles FJ, Hochhaus A, et al. Nilotinib in patients with $\mathrm{Ph}+$ chronic myeloid leukemia in accelerated phase following imatinib resistance or intolerance: 24-month follow-up results. Leukemia 2012;26:1189-1194.

[101] Hehlmann R. How I treat CML blast crisis. Blood 2012;120:737-747.

[102] Sureda A, Carrasco M, de Miguel M, et al. Imatinib mesylate as treatment for blastic transformation of Philadelphia chromosome positive chronic myelogenous leukemia. Haematologica 2003;88:1213-1220.

[103] Cortes J, Rousselot P, Kim DW, et al. Dasatinib induces complete hematologic and cytogenetic responses in patients with imatinib-resistant or -intolerant chronic myeloid leukemia in blast crisis. Blood 2007;109:3207-3213.

[104] Saglio G, Hochhaus A, Goh YT, et al. Dasatinib in imatinibresistant or imatinib-intolerant chronic myeloid leukemia in blast phase after 2 years of follow-up in a phase 3 study: efficacy and tolerability of 140 milligrams once daily and 70 milligrams twice daily. Cancer 2010;15(116):3852-3861.

[105] Iacoboni SJ, Plunkett W, Kantarijan HM, et al. High dose cytosine arabinoside: treatment and cellular pharmacology of chronic myelogenous leukemia blast crisis. J Clin Oncol 1986;4:1079-1088.

[106] Marks SM, Baltimore D, McCaffrey R. Terminal transferase as a predictorof initial responsivenessto vincristine and prednisone in blastic chronic myelogenous leukemia. NEJM 1978;298:812-814.

[107] Cortes JE, Kim D, Pinilla-Ibarz J, et al. PACE: A pivotal phase II trial of ponatinib in patients with CML and Ph+ALL resistant or intolerant to dasatinib or nilotinib, or with the T315I mutation. JCO 2012;15. Abs 6503.
[108] Simonsson B, Oberg G, Bjoreman M, et al. Intensive treatment and stem cell transplantation in chronic myelogenous leukemia: long-term follow-up. Acta Haematol 2005;113:155-162.

[109] Gratwohl A, Hermans J, Goldman JM, et al. Risk assessment for patients with chronic myeloid leukaemia before allogeneic blood or marrow transplantation. Chronic Leukemia Working Party of the European Group for Blood and Marrow Transplantation. Lancet 1998;352:1087-1092.

[110] Gratwohl A, Brand R, Apperley J, et al., Chronic Leukemia Working Party of the European Group for Blood and Marrow Transplantation. Allogeneic hematopoietic stem cell transplantation for chronic myeloid leukemia in Europe 2006: transplant activity, long-term data and current results. An analysis by the Chronic Leukemia Working Party of the European Group for Blood and Marrow Transplantation (EBMT). Haematologica 2006;91:513-521.

[111] Apperley J. CML in pregnancy and childhood. Best Pract Res Clin Haematol 2009;22:455-474.

[112] Ault P, Kantarjian H, O'Brien S, et al. Pregnancy among patients with chronic myeloid leukemia treated with imatinib. J ClinOncol 2006;24:1204-1208.

[113] Hoch RV, Soriano P. Roles of PDGF in animal development. Development 2003;130:4769-4784.

[114] Pye SM, Cortes J, Ault P, et al. The effects of imatinib on pregnancy outcome. Blood 2008;111:5505-5508.

[115] Breccia M, Cannella L, Montefusco E, et al. Male patients with chronic myeloid leukemia treated with imatinib involved in healthy pregnancies: report of five cases. Leuk Res 2008;32:519-520. 